\title{
Electrophysiological Characterization of a Putative Supporting Cell Isolated from the Frog Taste Disk
}

\author{
Albertino Bigiani, ${ }^{1}$ Andrea Sbarbati, ${ }^{2}$ Francesco Osculati, ${ }^{2}$ and Pierangelo Pietra ${ }^{1}$ \\ ${ }^{1}$ Dipartimento di Scienze Biomediche, Sezione di Fisiologia, Università di Modena, 41100 Modena, Italy, and 2/stituto di \\ Anatomia ed Istologia, Università di Verona, 37134 Verona, Italy
}

\begin{abstract}
Chemosensory cells in vertebrate taste organs have two obvious specializations: an apical membrane with access to the tastants occurring in food, and synapses with sensory axons. In many species, however, certain differentiated taste cells have access to the tastants but lack any synaptic contacts with axons, and a supportive rather than chemosensory function has been attributed to them. Until now, no functional data are available for these taste cells. To begin to understand their role in taste organ physiology, we have characterized with patchclamp recording techniques the electrophysiological properties of a putative supporting cell-the so-called wing cell-isolated from frog taste disks. Wing cells were distinguished from chemosensory elements by the presence of a typical, sheet-like apical process. Their resting potential was approximately -52 $\mathrm{mV}$, and the average input resistance was $4.8 \mathrm{G} \Omega$. Wing cells possessed voltage-gated $\mathrm{Na}^{+}$currents sensitive to TTX, and
\end{abstract}

an inactivating, voltage-gated $\mathrm{K}^{+}$current sensitive to TEA. Current injections elicited single action potentials but not repetitive firing. We found no evidence for voltage-gated $\mathrm{Ca}^{2+}$ currents under various experimental conditions. Amiloridesensitive $\mathrm{Na}^{+}$channels, thought to be involved in $\mathrm{Na}^{+}$chemotransduction, were present in wing cells. Many of the membrane properties of wing cells have been also reported for chemosensory taste cells. The presence of ion channels in wing cells might be suggestive of a role in controlling the microenvironment inside the taste organs or the functioning of chemosensory cells or both. In addition, they might participate directly in the sensory transduction events by allowing loop currents to flow inside the taste organs during chemostimulation.

Key words: frog; supporting cell; wing cell; gustatory; patch clamp; voltage-gated channel; amiloride-sensitive Na channel
Taste buds are the peripheral detectors of chemicals occurring in food. These pear-shaped sensory organs are made up of $\sim 100$ specialized epithelial cells called taste cells. On the basis of their structural features, taste cells have been divided into several categories, such as elongated cells (Type I, Type II, Type III) and basal cells (stem cells, Merkel-like cells) (for review, see Roper, 1989; Lindemann, 1996). Elongated cells reach the apex of taste buds (taste pore) where interaction with chemical stimuli occurs. Therefore, they are thought to be involved in the initial events of gustatory chemotransduction. On the contrary, basal cells lie at the bottom of the sensory organ without sending processes to the taste pore. Because sensory information needs to be transferred to afferent nerve fibers to reach the brain, taste chemosensory cells should present synaptic contacts with axons (Lindemann, 1996). However, in many vertebrate species (including mammals), not all elongated cells form synapses. This morphological observation has led to postulation of the existence of supporting (nonsensory) cells in taste buds (for review, see Roper, 1989; Lindemann, 1996). Putative supporting cells are considered secretory elements lacking specialized contacts with axons. Until now, information on the membrane properties of these cells,

Received March 9, 1998; revised April 23, 1998; accepted April 27, 1998.

This study was supported in part by the Italian Ministero dell'Università e della Ricerca Scientifica e Tecnologica. We thank Dr. Stephen D. Roper (University of Miami) for critically reviewing this manuscript. We thank Mr. Fausto Vaccari (Università di Modena) and Mr. Paolo Bernardi (Università di Verona) for their excellent technical assistance.

Correspondence should be addressed to Dr. Albertino Bigiani, Dipartimento di Scienze Biomediche, Sezione di Fisiologia, Università di Modena, via Campi 287, 41100 Modena, Italy.

Copyright (ㄷ) 1998 Society for Neuroscience $\quad 0270-6474 / 98 / 185136-15 \$ 05.00 / 0$ which could help to define their role in taste bud physiology, is not available, whereas a great deal of information about the electrophysiological properties of chemosensory cells has been obtained by applying the patch-clamp technique to taste cells identified with morphological techniques (Avenet and Lindemann, 1987; McPheeters et al., 1994; Bigiani et al., 1996).

We have examined the question of the membrane properties of taste supporting cells by applying the patch-clamp technique to cells isolated from frog taste organs. In this amphibian, taste cells are clustered in quite large structures called taste disks. Frog taste disks contain all the main morphotypes of taste cells described in vertebrates, and their ultrastructure is well documented (for review, see Osculati and Sbarbati, 1995). We have focused our attention on a cell type termed wing cell (Jaeger and Hillman, 1976; Richter et al., 1988; Osculati and Sbarbati, 1995). Wing cells (also termed Type I cells) are differentiated cells that lack any obvious synaptic contacts with afferent axons (for review, see Osculati and Sbarbati, 1995). Wing cells possess a sheet-like process that reaches the free surface of the taste disk, and therefore they can be readily identified after isolation and distinguished from chemosensory cells, which present a rod-like apical process (Avenet and Lindemann, 1987; Richter et al., 1988). This paper describes the membrane properties of wing cells and compares these properties with those from chemosensitive rod cells (Avenet and Lindemann, 1987, 1988; Miyamoto et al., 1991).

\section{MATERIALS AND METHODS}

Isolation of taste cells. Frogs of the species Rana esculenta (complex) were obtained from commercial suppliers and maintained in the laboratory at $\sim 10^{\circ} \mathrm{C}$ with access to tap water. Animals were decapitated and pithed, and their tongues were removed. In frogs, taste cells are clustered in taste 

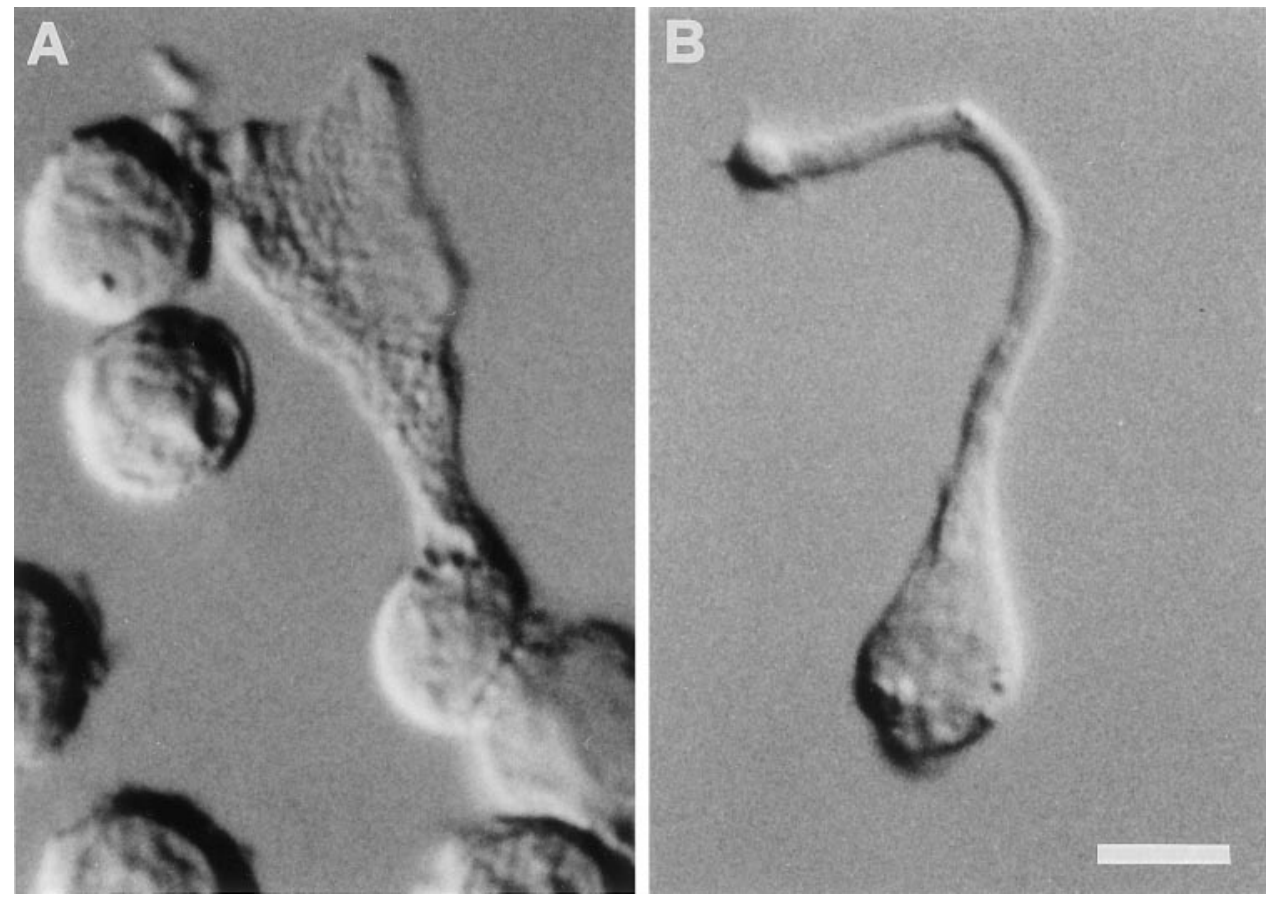

Figure 1. Differential interference contrast photomicrographs of living taste cells isolated from the frog taste disk. $A$, A wing (supporting) cell characterized by its wide, sheet-like apical process. $B$, A chemosensory cell characterized by the rod-like apical process. Scale bar, $5 \mu \mathrm{m}$.
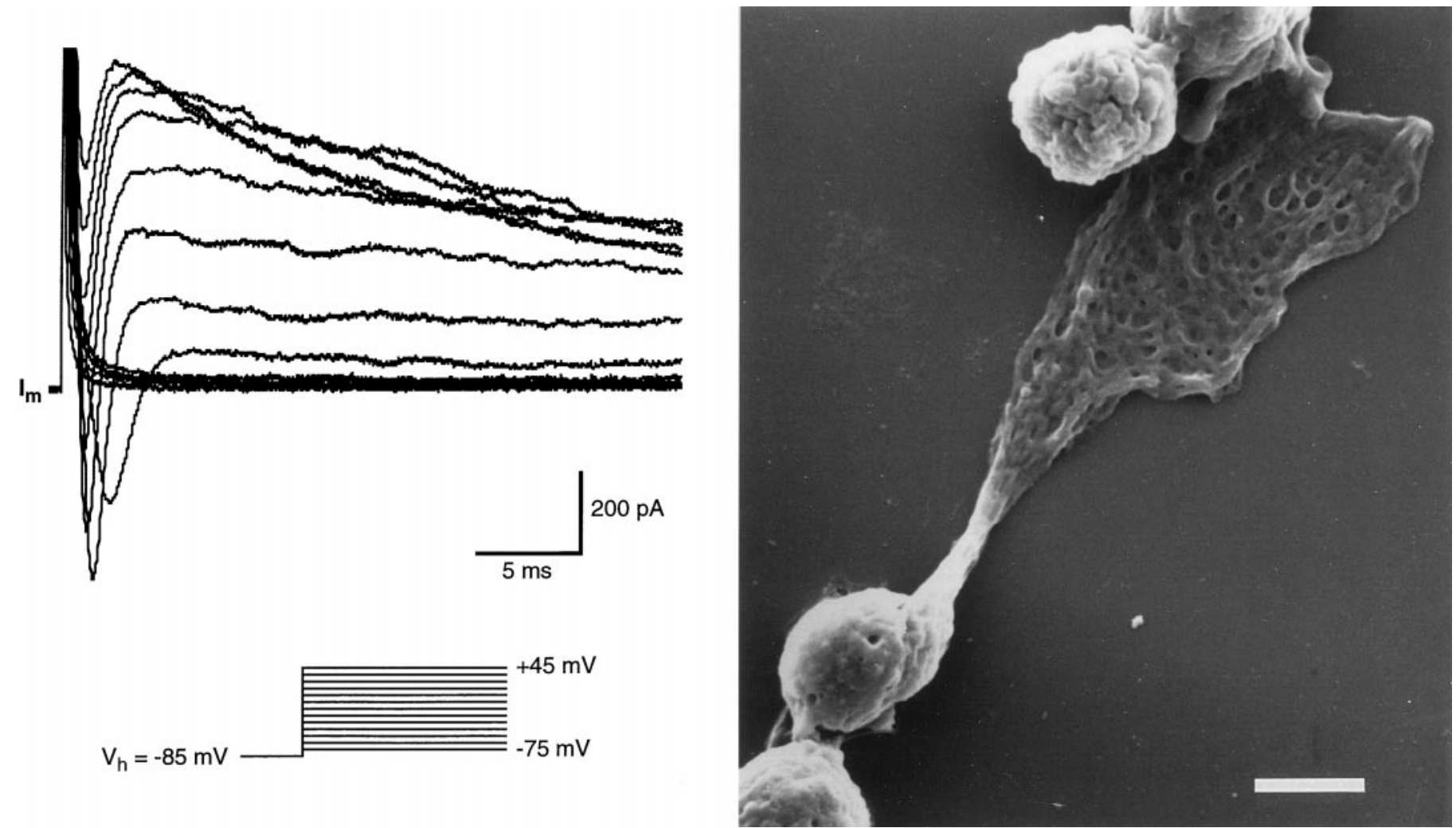

Figure 2. Whole-cell currents recorded from the wing cell shown in Figure $1 A$. The cell membrane was held at $-85 \mathrm{mV}$ and stepped in $10 \mathrm{mV}$ increments from -75 to $+45 \mathrm{mV}$. Capacitative and leakage currents were not subtracted from the records. Bath perfusion was APS; pipette solution was standard $105 \mathrm{~mm} \mathrm{KCl}$. After recording and adequate processing, this cell was observed at the scanning electron microscope to confirm its identity. From the photomicrograph on the right it is possible to recognize readily the typical wide process that characterizes wing cells. Scale bar, $5 \mu \mathrm{m}$.

disks located at the top of fungiform papillae (Jaeger and Hillman, 1976). Isolated taste disks were obtained by cutting the stem of fungiform papillae with fine scissors under a dissection microscope. From one tongue, $\sim 150$ fungiform papillae were cut off and then washed in an amphibian physiological solution (APS) containing (in $\mathrm{mm}$ ): $110 \mathrm{NaCl}, 2$
$\mathrm{KCl}, 2 \mathrm{CaCl}_{2}, 1 \mathrm{MgCl}_{2}, 20$ glucose, 10 HEPES, buffered to $\mathrm{pH} 7.2$ with $\mathrm{NaOH}$. Isolated taste cells were obtained by applying an enzymaticmechanical treatment to dissociated fungiform papillae, as described previously (Fujiyama et al., 1993, 1994; Okada et al., 1994). Briefly, 1 $\mathrm{mg} / \mathrm{ml}$ papain (Sigma, St. Louis, MO) was added to a divalent ion-free 
A
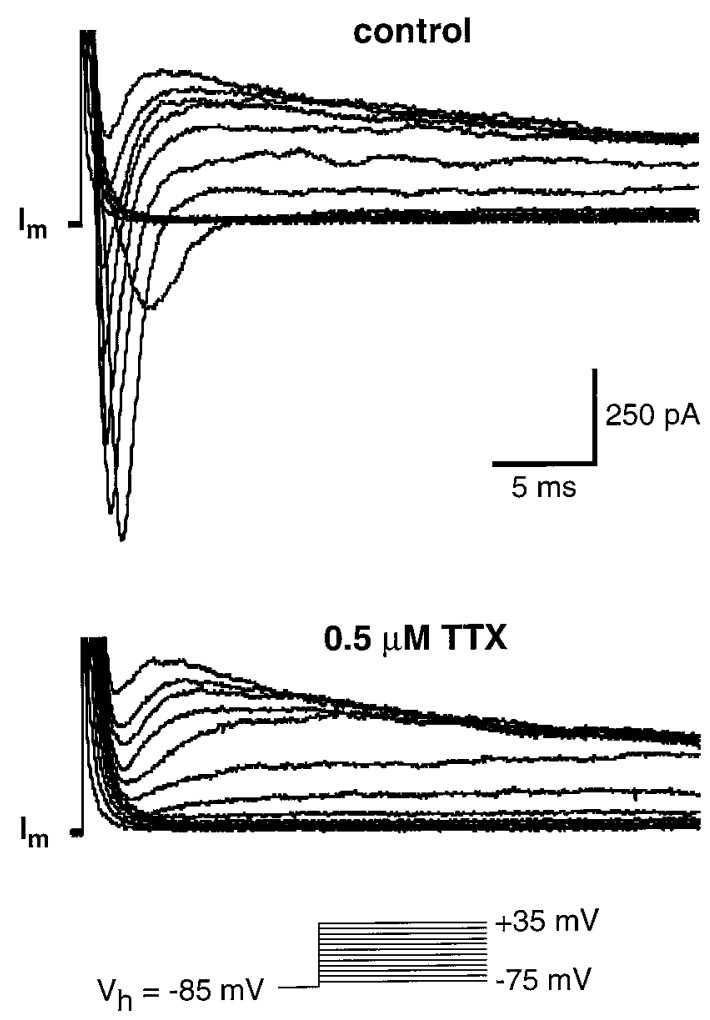

B
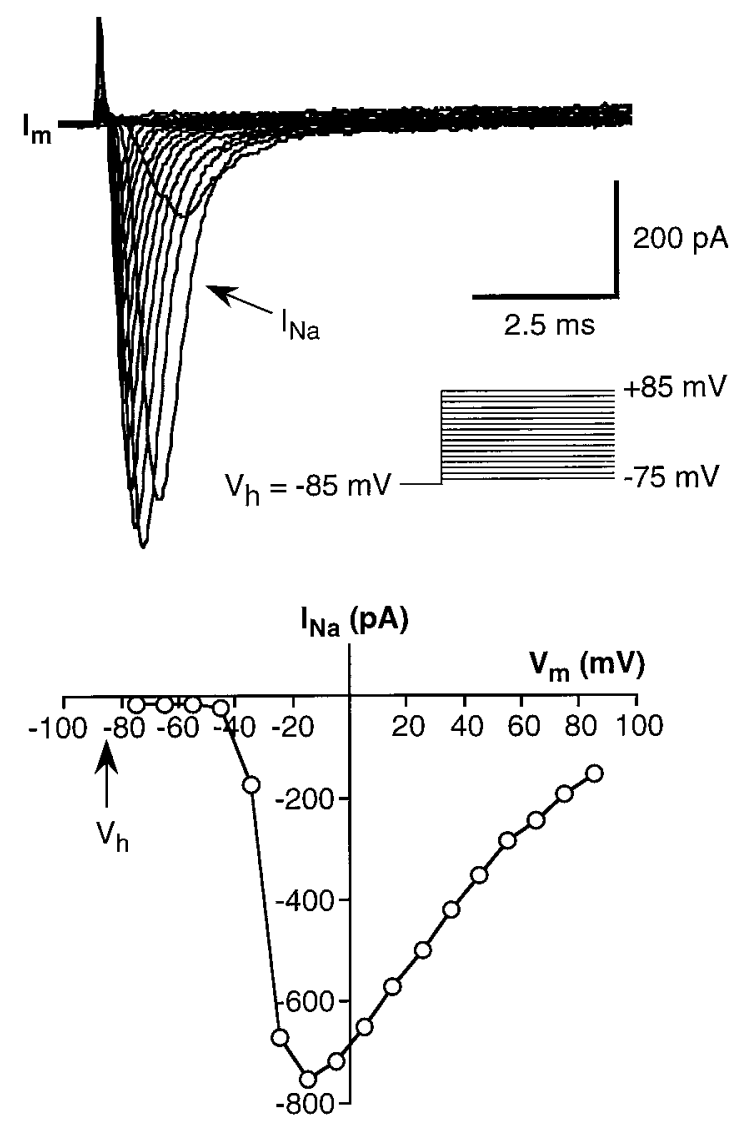

Figure 3. Voltage-gated $\mathrm{Na}^{+}$currents in wing cells. $A$, Whole-cell currents elicited in an isolated wing cell by a series of depolarizing pulses between -75 and $+35 \mathrm{mV}$, in $10 \mathrm{mV}$ increments, from a holding potential of $-85 \mathrm{mV}$. During bath perfusion with $0.5 \mu \mathrm{M}$ TTX, the transient inward current was completely blocked, indicating that it was a $\mathrm{Na}^{+}$current. $I_{\mathrm{m}}$, Membrane currents. Capacitative and leakage currents were not subtracted from the records. Pipette solution was standard $105 \mathrm{~mm} \mathrm{KCl.} B$, A family of $\mathrm{Na}^{+}$currents recorded from an isolated wing cell. Currents $\left(I_{\mathrm{m}}\right)$ were elicited by stepping the membrane held at $-85 \mathrm{mV}$ from -75 to $+85 \mathrm{mV}$ in $10 \mathrm{mV}$ increments. Capacitative and leakage currents were subtracted from the records. Bath, APS; pipette solution, standard $105 \mathrm{~mm} \mathrm{CsCl}$. Current-voltage relationship for the peak transient inward current reveals that voltage-gated Na ${ }^{+}$ current activated at approximately $-40 \mathrm{mV}$ and reached a maximum value at approximately $-15 \mathrm{mV}$ in this wing cell.

APS containing $2 \mathrm{~mm}$ EDTA and $1 \mathrm{mg} / \mathrm{ml}$ L-cysteine, and the solution was left at $23^{\circ} \mathrm{C}$ for $10 \mathrm{~min}$ to activate papain. The fungiform papillae were rinsed in divalent ion-free APS containing 2 mM EDTA for $10 \mathrm{~min}$ and then incubated at $23^{\circ} \mathrm{C}$ for $10 \mathrm{~min}$ in the activated papain solution. After enzymatic treatment, fungiform papillae were rinsed twice with standard APS and transferred ( $\sim 10$ taste disks at a time) into the recording chamber (a standard glass slide onto which a silicone ring of 1-2 $\mathrm{mm}$ thickness and $15 \mathrm{~mm}$ inner diameter was pressed). Individual taste cells were obtained by gentle trituration with a glass pipette having an opening of $\sim 100 \mu \mathrm{m}$. Dissociated cells were left to settle to the bottom of the recording chamber, which was treated previously with Cell-Tak $\left(\sim 3 \mu \mathrm{g} / \mathrm{cm}^{2}\right.$; Collaborative Research, Bedford, MA) to improve adherence of isolated cells to the glass slide. The chamber was placed on the stage of an upright Olympus microscope (model BHW I equipped with a $40 \times$ water-immersion objective, working distance $=3.1$ $\mathrm{mm}$ ), and taste cells were viewed with Nomarsky optics at $750 \times$. During the experiments, the chamber was continuously perfused with APS (flow rate: $2-3 \mathrm{ml} / \mathrm{min}$ ) by means of a gravity-driven system.

Recording techniques. In the majority of experiments, membrane ionic currents were monitored in taste cells using whole-cell configuration of the patch-clamp technique (Hamill et al., 1981). For testing voltage-gated $\mathrm{Ca}^{2+}$ currents, we used also the nystatin-perforated patch recording (Horn and Marty, 1988; Korn et al., 1991). This configuration of the patch-clamp technique allows whole-cell membrane currents to be recorded in the virtual absence of washout and with little disruption of endogenous cellular $\mathrm{Ca}^{2+}$ buffering mechanisms that may be involved in the rundown of $\mathrm{Ca}^{2+}$ currents (Belles et al., 1988; Korn and Horn, 1989). Patch pipettes were made from soda lime glass capillaries (Baxter Sci- entific Products, McGaw Park, IL) on a two-stage vertical puller (model PB-7; Narishige, Tokyo, Japan). Pipette resistance, when filled with standard intracellular solution, was typically in the 4-8 M $\Omega$ range. Cell-attached seal resistances were in the range of 5-30 G $\Omega$ with both types of recording configurations. In some experiments, patch pipettes were coated with Sylgard (Dow Corning, Midland, MI) to reduce stray capacitance.

Whole-cell membrane currents were recorded at room temperature $\left(20-22^{\circ} \mathrm{C}\right)$ using an Axopatch amplifier (model 1D; Axon Instruments, Foster City, CA). Signals were recorded and analyzed using a 486-based computer equipped with a Digidata 1200 data acquisition system and pCLAMP software (Axon Instruments). Signal filtering and digitization were adjusted according to the specific features of the membrane currents. For voltage-gated currents, signals were prefiltered at $5 \mathrm{kHz}$ and digitally recorded at $25 \mu \mathrm{sec}$ intervals; for amiloride-sensitive currents, signals were usually prefiltered at $200-500 \mathrm{~Hz}$ and digitized at $3-10 \mathrm{msec}$ intervals.

The access resistance of the patch pipette tip was estimated by dividing the amplitude of the voltage steps by the peak of the capacitive transients (from which stray capacitance had been subtracted). In whole-cell configuration, values typically ranged from $\sim 10$ to $25 \mathrm{M} \Omega$. In perforatedpatch configuration, after obtaining the high-resistance seal, access resistance was monitored periodically to check the diffusion of nystatin into the cell membrane. Access to the cell interior was judged by the first appearance of a transient capacitive transient (Horn and Marty, 1988). We usually began our experiments when the access resistance dropped to $<50 \mathrm{M} \Omega$. 
A
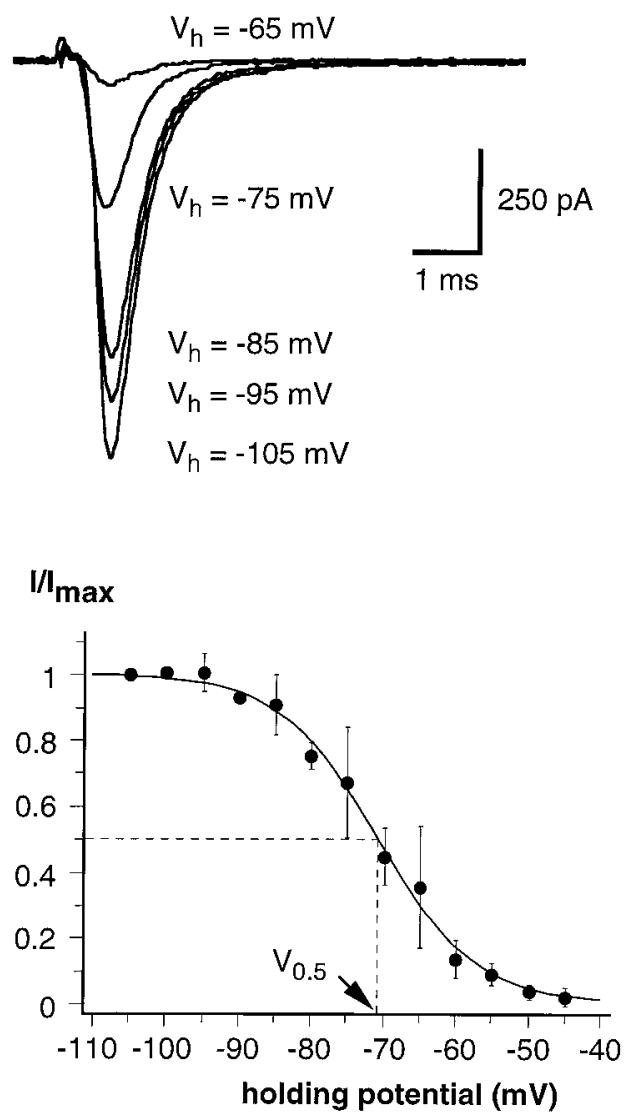

B
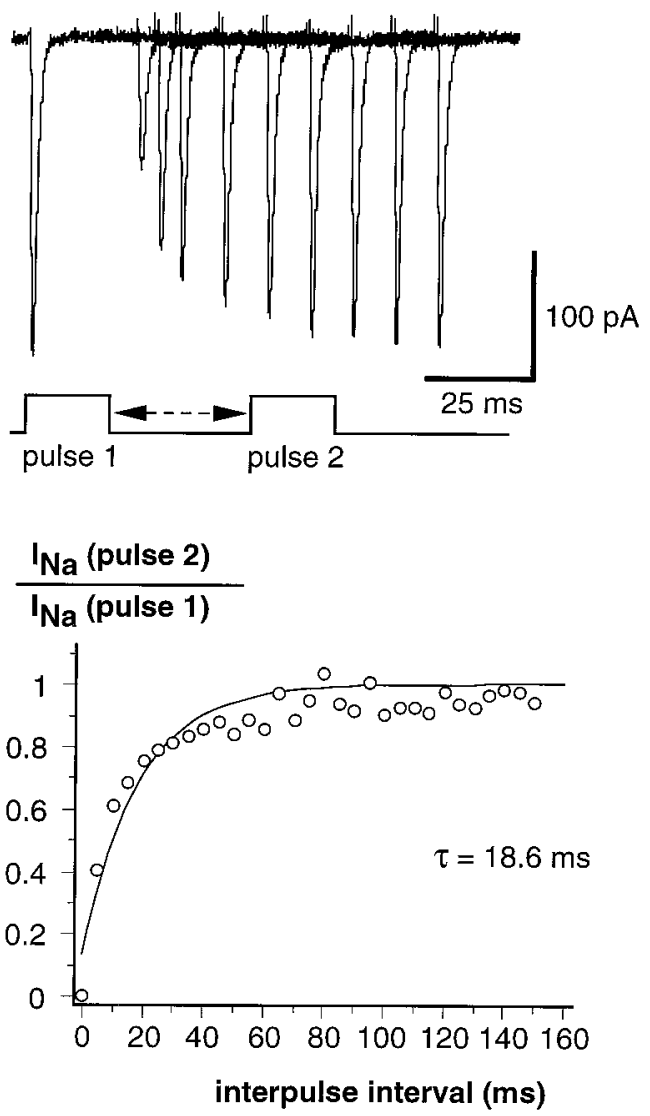

Figure 4. Properties of the inactivation of voltage-gated $\mathrm{Na}^{+}$currents in wing cells. $A$, Voltage-dependence of the steady-state inactivation. Maximal peak inward $\mathrm{Na}^{+}$currents recorded after holding the membrane for $10 \mathrm{sec}$ at $-105,-95,-85,-75$, and $-65 \mathrm{mV}\left(V_{\mathrm{h}}\right)$. Note that the Na${ }^{+}$currents decreased at less negative potentials (inactivation). Capacitative and leakage currents were subtracted from the records. Bath solution, APS; pipette solution, standard $105 \mathrm{~mm} \mathrm{CsCl}$. In the steady-state inactivation-voltage relationship (bottom), the maximal peak $\mathrm{Na}^{+}$currents $(I)$ obtained for holding potentials between -105 and $-45 \mathrm{mV}$ were normalized with respect to that obtained with $V_{\mathrm{h}}=-105 \mathrm{mV}\left(I_{\max }\right)$, and then plotted against the holding potential. Each point represents the mean $\pm \mathrm{SD}$ of two to seven values from seven wing cells. Data were fitted by a sigmoid curve. The calculated half-maximal voltage $\left(V_{0.5}\right)$ was $-70.7 \mathrm{mV}$, and the slope was $6.8 \mathrm{mV} . B$, Recovery from inactivation for voltage-gated $\mathrm{Na}^{+}$currents at $-85 \mathrm{mV}$. Na ${ }^{+}$ currents were elicited with a two-pulse protocol. The first $20 \mathrm{msec}$ pulse moved the voltage from a holding potential of -85 to $-15 \mathrm{mV}$. After a variable delay spent at $-85 \mathrm{mV}$, a second 20 msec pulse of the same amplitude was applied to the cell membrane and the current was recorded. Current elicited by the second pulse was measured and normalized to the first preceding pulse and plotted against the interpulse interval. Data points could be fitted approximately by a single exponential function with a time constant of $18.6 \mathrm{msec}$ for the cell shown here.

As a rule, we adjusted the pipette potential for zero-current flow before establishing a seal: this zero-current potential was the reference for subsequent measurements. Because pipette and bath contained different solutions, a liquid junction potential (LJP) developed at the tip of the pipette (for review, see Barry and Lynch, 1991). This potential, measured as described by Neher (1992), was $\sim 5 \mathrm{mV}$ (pipette solution negative) with the pipette solutions used in whole-cell recordings, and $\sim 7$ $\mathrm{mV}$ with the pipette solution used in perforated-patch recording. All data have been corrected for these LJPs.

Solutions for electrophysiology. Our standard bathing medium was the APS. Drugs were dissolved in standard or modified APS solutions and bath-applied. Gravity-fed test solutions were controlled by multisolenoid manifold valves (General Valve Corp., Fairfield, NJ) and introduced through a common inlet into the recording chamber. To reveal voltagegated $\mathrm{Ca}^{2+}$ currents, we used the following bath solution (concentrations in mM): $25 \mathrm{BaCl}_{2}, 80$ TEACl, 0.001 tetrodotoxin (TTX), 20 glucose, 10 HEPES, buffered to $\mathrm{pH} 7.2$ with TEAOH. Two different pipette solutions were used, depending on the configuration of the patch-clamp recording. For whole-cell recording, the pipette solution contained (in $\mathrm{mM}$ ): $105 \mathrm{KCl}, 2 \mathrm{MgCl}_{2}, 5$ EGTA, 10 HEPES, buffered to $\mathrm{pH} 7.2$ with $\mathrm{KOH}$. In some experiments, $\mathrm{KCl}$ was replaced by an equal concentration of $\mathrm{CsCl}$, and the solution was buffered to $\mathrm{pH} 7.2$ with $\mathrm{CsOH}$. For perforated-patch recording, nystatin was dissolved in dimethyl sulfoxide (DMSO) with constant stirring to yield a stock solution of $50 \mathrm{mg} / \mathrm{ml}$. The nystatin stock solution was prepared fresh for each experiment. Nystatin was added to a pipette solution consisting of (in $\mathrm{mM}$ ): $55 \mathrm{CsCl}, 25$ $\mathrm{Cs}_{2} \mathrm{SO}_{4}, 8 \mathrm{MgCl}_{2}, 10 \mathrm{HEPES}$, buffered to $\mathrm{pH} 7.2$ with $\mathrm{CsOH}$, to give a final nystatin concentration of $250 \mu \mathrm{g} / \mathrm{ml}$. The tip of the patch pipette was filled with nystatin-free solution and backfilled with nystatin solution. All chemicals were from Sigma, except TTX (Affinity, Nottingham, UK).

Scanning electron microscopy. After electrophysiological recording, some wing cells were processed with standard protocols (Zancanaro et al., 1990) for observation with a scanning electron microscope. Briefly, isolated cells were fixed in the recording chamber with $2.5 \%$ glutaraldehyde (BDH, Poole, England) in $0.1 \mathrm{M}$ sodium cacodylate buffer (SCB) at $\mathrm{pH} 7.2$ for $\sim 20 \mathrm{~min}$. During this period, patch pipette was left on the cell to avoid detachment of the isolated cell from the bottom of the recording chamber. In whole-cell recording, progress of fixation could be monitored by observing the disappearance of voltage-gated currents: the patch pipette was thereafter removed, leaving the recorded cell attached to the glass slides. At this stage, cells were photographed for later identification at the electron microscope. Slides were stored overnight in fixative at $4^{\circ} \mathrm{C}$. Specimens were then rinsed with $0.1 \mathrm{M}$ phosphate buffer, $\mathrm{pH} 7.2$, and processed for electron microscopic observations: to this end, cells were post-fixed in $1 \% \mathrm{OsO}_{4}$ in $\mathrm{SCB}$ for $1 \mathrm{hr}$, rinsed with distilled water, dehydrated through a graded ethanol series, critical-point dried, and finally coated with gold. Specimens were observed under a Zeiss 950 
A
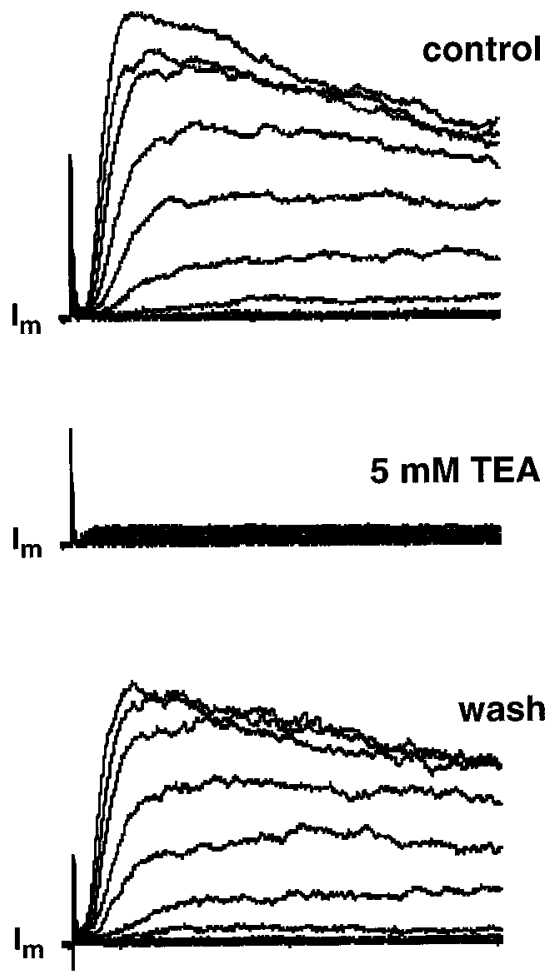

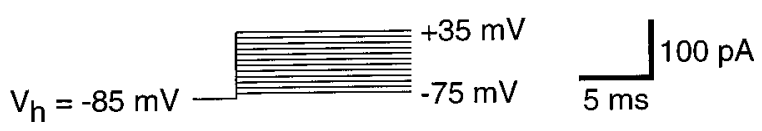

B
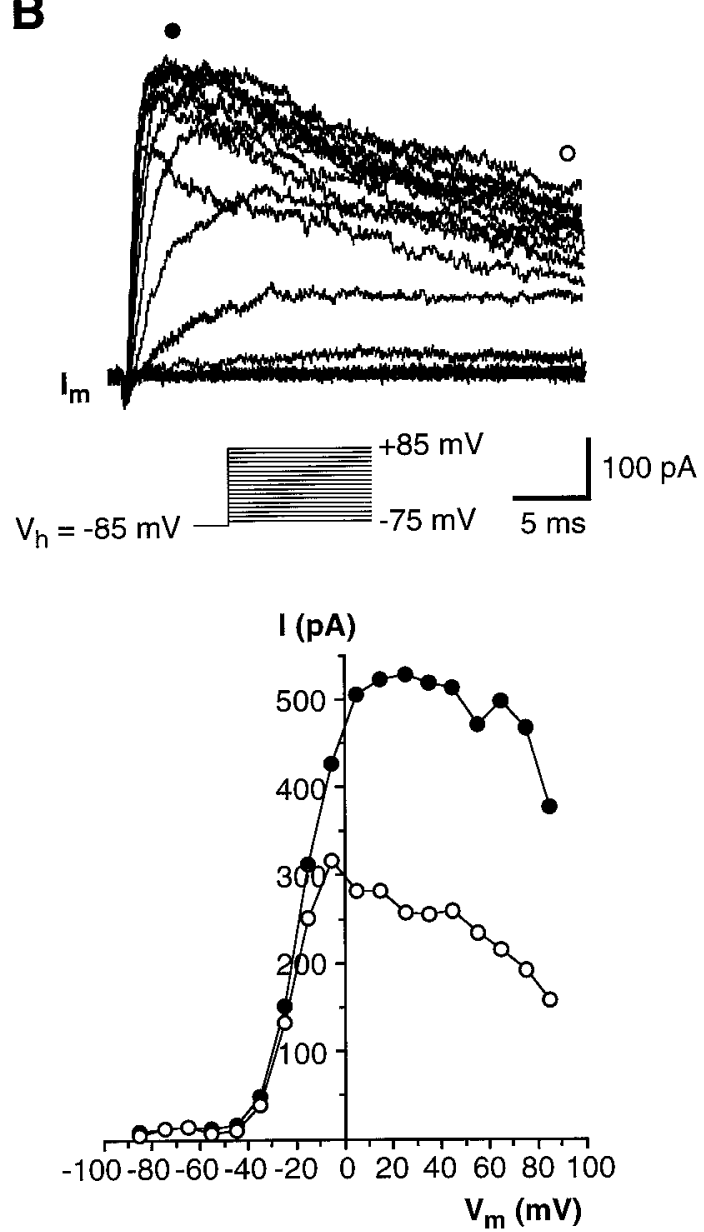

Figure 5. Voltage-gated $\mathrm{K}^{+}$currents in wing cells. $A$, TEA sensitivity of the outward currents recorded from an isolated wing cell. Voltage-gated Na ${ }^{+}$ currents were blocked by adding $0.5 \mu \mathrm{M}$ TTX to all solutions. Membrane currents $\left(I_{\mathrm{m}}\right)$ were elicited by a series of depolarizing pulses between -75 and $+35 \mathrm{mV}$, in $10 \mathrm{mV}$ increments, from a holding potential of $-85 \mathrm{mV}$. Capacitative and leakage currents were subtracted from the records. Outward currents recorded in regular APS (control, top) were totally abolished by $5 \mathrm{~mm}$ TEA (middle). The effect was reversible, as indicated by the recovery of

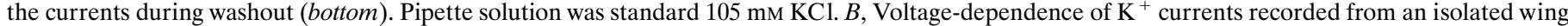
cell. A family of currents $\left(I_{\mathrm{m}}\right)$ was elicited by stepping the cell membrane, held at $-85 \mathrm{mV}$, from -75 to $+45 \mathrm{mV}$ in $10 \mathrm{mV}$ increments. Capacitative and leakage currents were subtracted from the records. Bath perfusion was APS $+0.2 \mu \mathrm{M}$ TTX to block voltage-gated Na ${ }^{+}$currents. Pipette solution was standard $105 \mathrm{~mm} \mathrm{KCl}$. In the $I-V$ plot, both the peak value $(\bullet)$ and the value measured at the end of the voltage pulse $(\bigcirc)$ are shown. It can be noted that the peak current after reaching a maximal value between approximately 20 and $40 \mathrm{mV}$ decreases with further depolarization.

scanning electron microscope. To relocate wing cells, light and electron micrographs were matched to identify the recorded cells unequivocally.

\section{RESULTS}

\section{Identification of isolated supporting (wing) cells}

Frog taste disks contain elongated cells (classified as Type I, Type II, and Type III cells) and basal cells (for review, see Osculati and Sbarbati, 1995). Wing cells (Type I cells) possess one apical sheet-like process reaching the free surface of the taste organ. The apical process characterizes these cells, and we used it as a morphological marker. In fact, after the papain-low $\mathrm{Ca}$ treatment, wing cells could be readily identified by the presence of their typical process (Fig. 1A), whereas other isolated taste cells, such as those with a rod-like apical process (Type II and Type III, which are considered to be chemosensory) (Avenet and Lindemann, 1987; Richter et al., 1988; Osculati and Sbarbati, 1995), could be easily distinguished from wing cells (Fig. 1B). Under our experimental conditions, wing cells retained their typical morphology after isolation and plating on the glass slide. Some wing cells were fixed after patch recordings and processed for scanning electron microscopy to further confirm their identity. Figure 2 shows an electron micrograph of the wing cell shown in Figure 1. It can be noted that the wide apical process presents several plasmalemmal pits and ridges that may represent the contact points with adjacent cells in the intact taste disk (Osculati and Sbarbati, 1995). In this study, we present data obtained from 137 unambiguously identified wing cells. Just for the purpose of comparison, we also report data obtained from 26 rod cells (i.e., the chemosensory cells according to Avenet and Lindemann, 1987; Richter et al., 1988; Osculati and Sbarbati, 1995). A detailed analysis of membrane properties of rod cells is included in published reports (Avenet and Lindemann, 1987, 1988; Miyamoto et al., 1988, 1991).

\section{Passive membrane properties}

After the patch was broken and whole-cell recordings were established, wing cells had a zero-current voltage $\left(V_{0}\right.$, assumed to be an estimation of the cell resting potential) of $-52 \pm 6 \mathrm{mV}$ (mean $\pm \mathrm{SD}$; range $-41 \mathrm{mV}$ to $-61 \mathrm{mV} ; n=19$ ) when normal APS was used in the bath and the pipette filling solution con- 
A
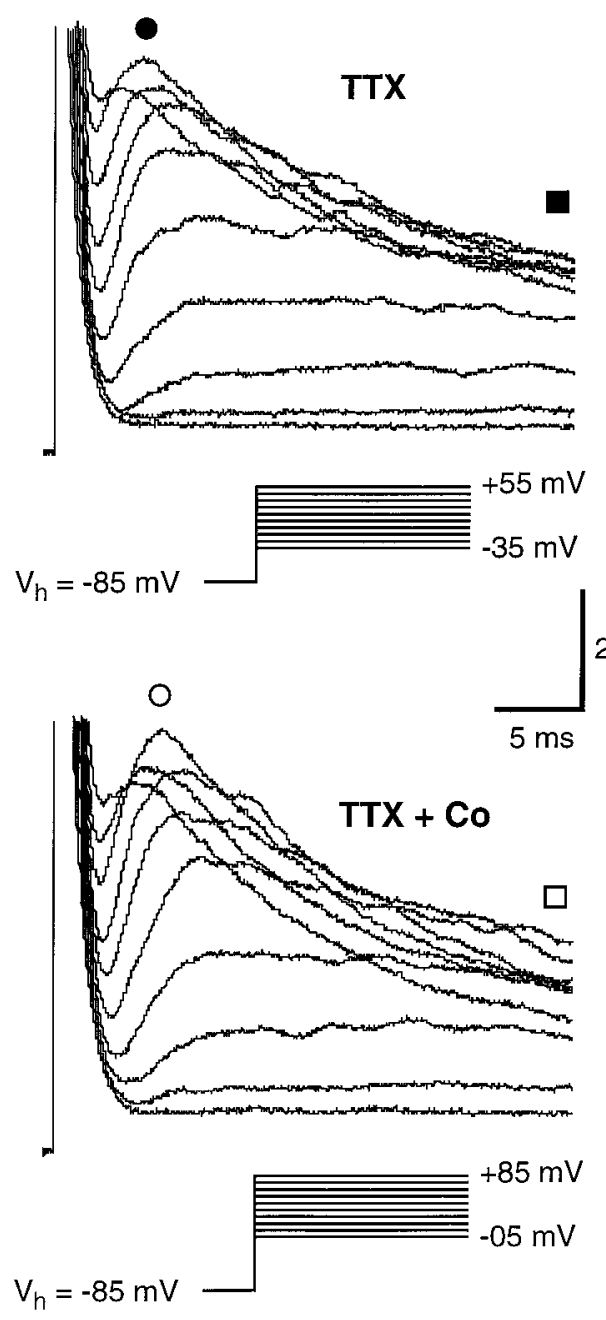

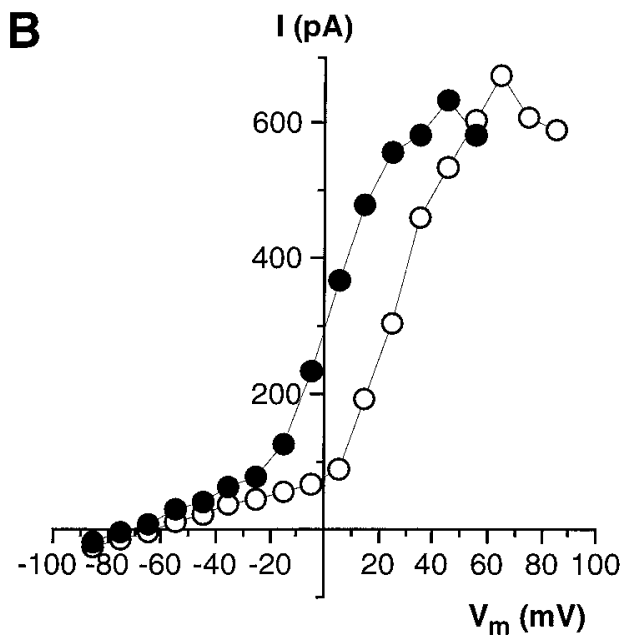

$200 \mathrm{pA}$

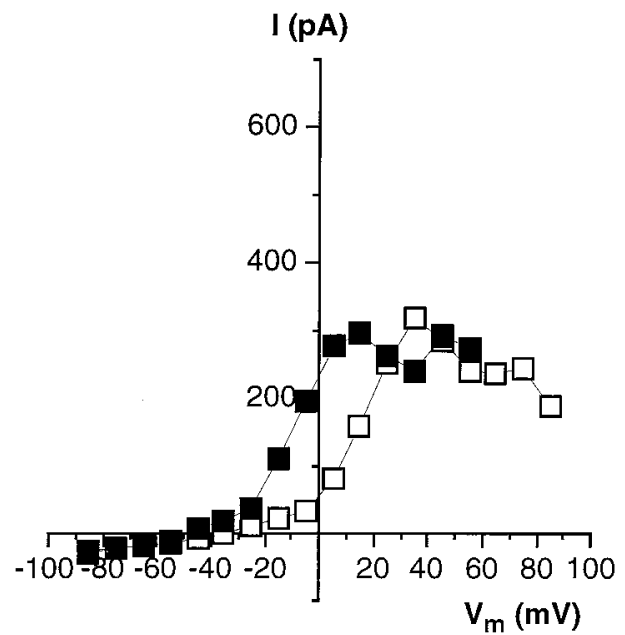

Figure 6. Effect of $\mathrm{Co}^{2+}$ on the voltage-gated $\mathrm{K}^{+}$currents recorded from an isolated wing cell. $A$, Sample currents elicited by a series of depolarizing voltage pulses from a holding potential of $-85 \mathrm{mV}$ when the cell was bathed in regular APS (top) and in the presence of $10 \mathrm{mM}$ Co ${ }^{2+}$ (bottom). TTX $(0.5 \mu \mathrm{M})$ was added to all bath solutions to block voltage-gated $\mathrm{Na}^{+}$channels. Pipette solution was standard $105 \mathrm{mM} \mathrm{KCl}$. Capacitative and leakage currents were not subtracted from the records. $B, I-V$ plots for the peak value (circles) and the value at the end of the voltage pulses (squares) of the outward current elicited in regular APS ( filled symbols) and during $\mathrm{Co}^{2+}$ application (open symbols). $\mathrm{Co}^{2+}$ caused the $I-V$ relationship to shift in a positive direction.

tained $105 \mathrm{~mm} \mathrm{KCl}$. Changes in $V_{0}$ during recordings were frequently observed and were probably related to variations in the pipette-membrane seal resistance (Barry and Lynch, 1991). Under the same conditions, $V_{0}$ of rod cells was $-58 \pm 8$ (mean $\pm \mathrm{SD}$; range $-48 \mathrm{mV}$ to $-74 \mathrm{mV} ; n=8)$, which was significantly different ( $t$ test; $p=0.03$ ) from that of wing cells. We are unsure of the physiological relevance of this significance given the high values for the input resistance $\left(R_{\text {in }}\right)$ of isolated taste cells. As reviewed recently by Barry and Lynch (1991), the patch-clamp technique has limitations in both cell-attached and whole-cell modes when cells with $R_{\text {in }}$ in the gigaohm range are studied. Patch-clamp measurements of $V_{0}$ may require significant corrections; otherwise they could lead to erroneous conclusions (Bigiani et al., 1996). Cell membrane capacitance $\left(C_{\mathrm{m}}\right)$ was significantly larger in wing cells $(20.0 \pm 4.0 \mathrm{pF}$, mean $\pm \mathrm{SD}$; range $12.9 \mathrm{pF}$ to $28.6 \mathrm{pF} ; n=28)$ than in rod cells $(6.0 \pm 2.2$, mean $\pm \mathrm{SD}$; range $2.9 \mathrm{pF}$ to $8.8 \mathrm{pF} ; n=11$ ). This is consistent with differences in membrane surface area of the apical processes between wing and rod cells. The somata of these cell types were of similar dimensions (Fig. 1). Finally, input resistance $\left(R_{\text {in }}\right)$ of wing cells evaluated as slope resistance of the current-voltage $(I-V)$ relationship at a holding potential of $-85 \mathrm{mV}$ was $4.8 \pm 2.3 \mathrm{G} \Omega($ mean $\pm \mathrm{SD}$; range $1.2 \mathrm{G} \Omega$ to $10.1 \mathrm{G} \Omega ; n=30)$, quite similar ( $t$ test; $p=0.29$ ) to that measured in rod cells $(4.1 \pm 2.2 \mathrm{G} \Omega$, mean $\pm \mathrm{SD}$; range $1.2 \mathrm{G} \Omega$ to $9.9 \mathrm{G} \Omega ; n=19) . R_{\text {in }}$ is usually taken as an estimation of the cell membrane resistance in patch-clamp studies, and the values we reported are in the range of those obtained for taste cells of other vertebrates (Kinnamon and Roper, 1988; Spielman et al., 1989; Akabas et al., 1990; Béhé et al., 1990; Sugimoto and Teeter, 1990; Bigiani and Roper, 1993; Chen et al., 1996; Miyamoto et al., 1996).

\section{Membrane currents under voltage clamp}

The presence of voltage-gated ion channels in wing cells was investigated by recording membrane currents elicited by voltage steps from a holding potential of $-85 \mathrm{mV}$. This value was 


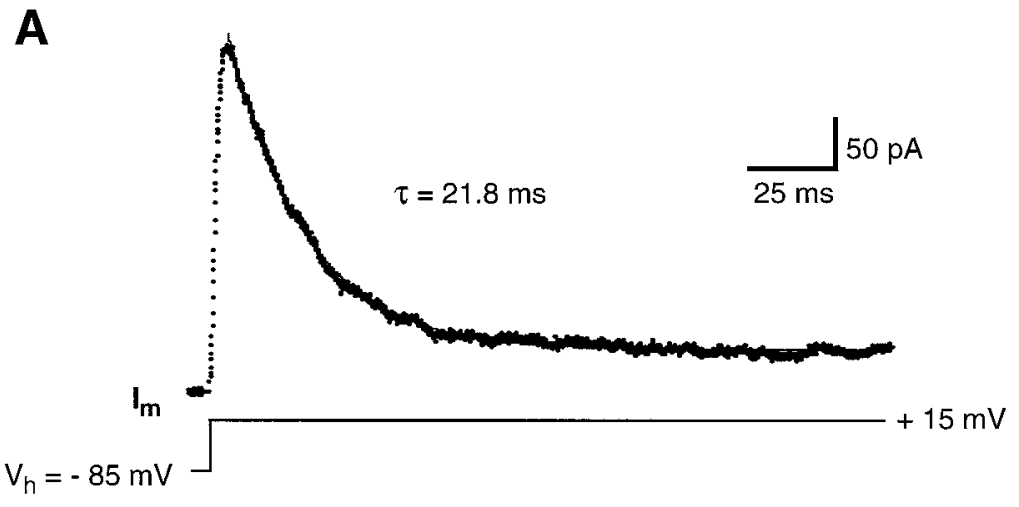

B
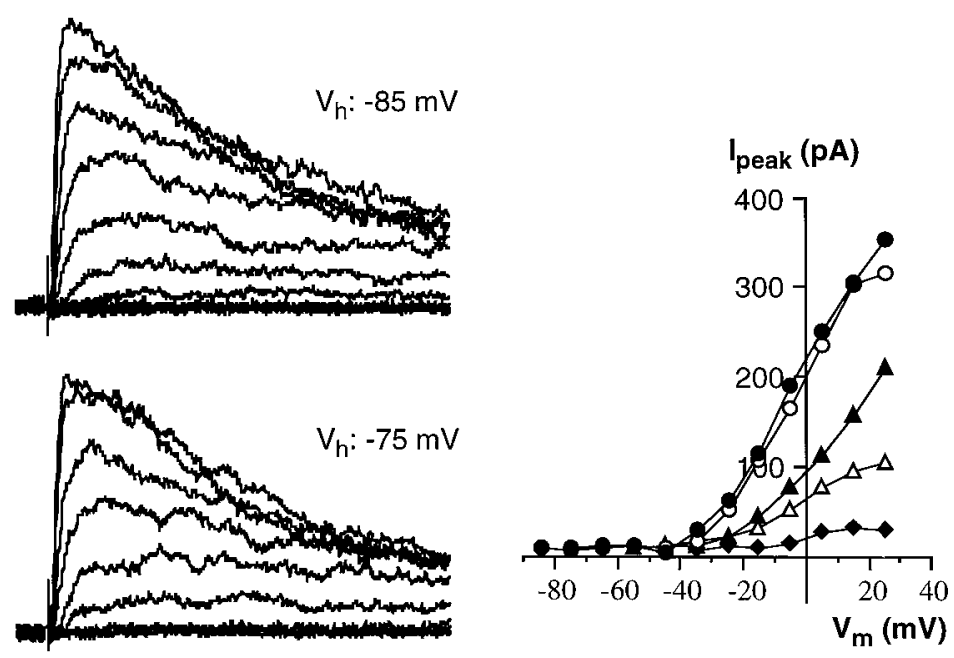

Figure 7. Properties of the inactivation of voltage-gated $\mathrm{K}^{+}$ currents in wing cells. $A$, Time course of inactivation of the $\mathrm{K}^{+}$ current recorded from an isolated wing cell. The membrane was held at $-85 \mathrm{mV}$ and stepped for $200 \mathrm{msec}$ to $+15 \mathrm{mV}$. The decay of the current was fit (solid line) with a single exponential function with a time constant of $21.8 \mathrm{msec}$ in this cell. $I_{\mathrm{m}}$, Membrane current. $B$, The effect of holding potential $\left(V_{\mathrm{h}}\right)$ on the inactivation of $\mathrm{K}^{+}$currents in another wing cell. Currents were elicited by a series of depolarizing voltage pulses in 10 $\mathrm{mV}$ increments from different holding potentials $\left(V_{\mathrm{h}}:-85\right.$, $-75,-55,-45$, and $-35 \mathrm{mV})$. All records are from the same cell. Bath solution was APS $+0.5 \mu \mathrm{M}$ TTX to block voltagegated $\mathrm{Na}^{+}$channels. Pipette solution was standard $105 \mathrm{mM}$ $\mathrm{KCl}$. Capacitative and leakage currents were subtracted from the records. The corresponding $I-V$ plots for the peak $\mathrm{K}^{+}$ currents elicited at different holding potentials are shown on the right.

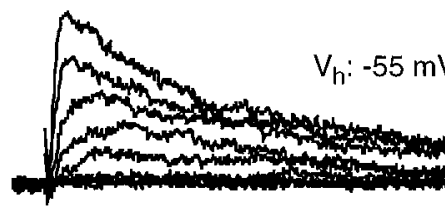

$$
\begin{aligned}
& \longrightarrow V_{h}:-85 \mathrm{mV} \\
& \longrightarrow-V_{h}:-75 \mathrm{mV} \\
& \triangle V_{h}:-55 \mathrm{mV} \\
& \square-V_{h}:-45 \mathrm{mV} \\
& \longrightarrow V_{h}:-35 \mathrm{mV}
\end{aligned}
$$$$
\mathrm{V}_{\mathrm{h}}:-45 \mathrm{mV}
$$

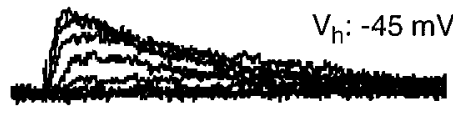

$$
\mathrm{V}_{\mathrm{h}}:-35 \mathrm{mV}
$$
$100 \mathrm{pA}$

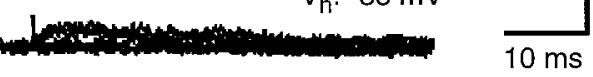

chosen as standard reference potential to compare membrane currents from different taste cells. With normal APS in the bath and the pipette filling solution containing $105 \mathrm{~mm} \mathrm{KCl}$, depolarizing voltage pulses elicited the current time courses shown in Figure 2. After an early capacitive transient, current showed a fast inward transient (plotted downward) followed by a pronounced outward trace, which developed more slowly and inactivated partially at positive voltages. These currents were observed in all wing cells that we tested under the above ionic conditions $(n=64)$, although their intensity varied from cell to cell (see below).

\section{Voltage-gated $\mathrm{Na}^{+}$currents}

The transient inward current was blocked reversibly by $0.5 \mu \mathrm{M}$ TTX (Fig. 3A) and disappeared when choline or $N$-methyl-Dglucamine (NMDG) replaced $\mathrm{Na}^{+}$in the bath (data not shown): in short, it was a $\mathrm{Na}^{+}$current. Properties of this current were additionally studied by replacing $\mathrm{KCl}$ of the pipette solution with $\mathrm{CsCl}$ to eliminate outward currents. With good space-clamp conditions, thresholds for $\mathrm{Na}^{+}$current activation ranged from -45 to $-35 \mathrm{mV}$. The peak current was reached between -15 and $-5 \mathrm{mV}$ and averaged $-750.7 \pm 301.5 \mathrm{pA}$ (mean $\pm \mathrm{SD}$; range -355.2 to $-1416.2 \mathrm{pA} ; n=22$ ). Figure $3 B$ shows a typical 


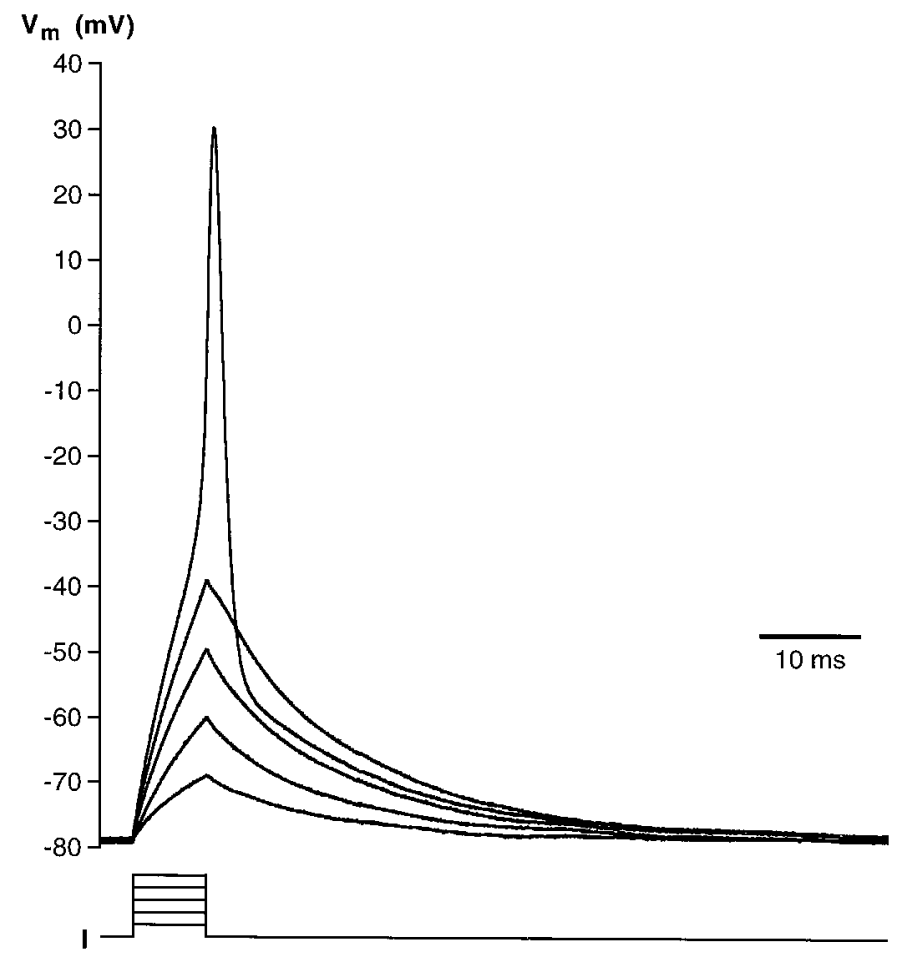

Figure 8. Action potential recorded from an isolated wing cell under current-clamp conditions. Cell membrane was held at approximately -80 $\mathrm{mV}$, and brief depolarizing current pulses in $2 \mathrm{pA}$ increments were injected. The first four pulses were subthreshold and failed to elicit action potentials. In this cell, the firing threshold was between -30 and $-40 \mathrm{mV}$. Pipette solution was standard $105 \mathrm{~mm} \mathrm{KCl} . V_{\mathrm{m}}$, Membrane potential.

example of the voltage dependence of these $\mathrm{Na}^{+}$currents. The $I-V$ relationship for voltage-gated $\mathrm{Na}^{+}$current in wing cells resembled that obtained from rod cells of the frog (Avenet and Lindemann, 1987; Miyamoto et al., 1988, 1991) as well as of taste cells from other vertebrate species (Kinnamon and Roper, 1988; Akabas et al., 1990; Béhé et al., 1990; Sugimoto and Teeter, 1990; Herness and Sun, 1995).

To study the voltage-dependence of the steady-state inactivation, the largest peak current $(I)$, as obtained with pulsed depolarization from different holding potentials $\left(V_{\mathrm{h}}\right.$, at which cells were held for $10 \mathrm{sec}$ ), was normalized to $I_{\max }$, measured at a holding potential of $-105 \mathrm{mV}$. The plot of $I / I_{\max }$ as a function of $V_{\mathrm{h}}$ resulted in a sigmoid curve (Fig. $4 A$ ) that could be fitted by the equation $I / I_{\max }=1 /\left\{1+\exp \left[\left(V-V_{0.5}\right) / k\right]\right\}$, where $\mathrm{V}_{0.5}$ is the membrane potential at which the current is $50 \%$ inactivated, and $k$ the slope. The value for the half-inactivation voltage was -70.7 $\mathrm{mV}$ and $k$ was $6.8 \mathrm{mV}$ (Fig. $4 A$ ) (pooled data from seven cells). We recall that according to Avenet and Lindemann (1987), inactivation was half-maximal at $-67 \mathrm{mV}$ in rod taste cells of the frog, whereas Herness and Sun (1995) reported a $V_{0.5}$ of $-65 \mathrm{mV}$ and a $k$ of $6.4 \mathrm{mV}$ for rat taste cells.

Recovery from inactivation was measured with a two-pulse protocol (Hille, 1992). The first pulse moved the voltage from -85 to $-15 \mathrm{mV}$, causing activation followed by full inactivation of the $\mathrm{Na}^{+}$channels. A second pulse, of the same amplitude, was applied after a variable delay $(t)$ spent at $-85 \mathrm{mV}$ (Fig. $4 B$ ). At this voltage, recovery from inactivation was approximately described by an exponential function, $[1-\exp (-t / \tau)]$, with a time constant $(\tau)$ of $15.5 \pm 5.6 \mathrm{msec}($ mean $\pm \mathrm{SD} ; n=4)$. This value is in good agreement with the time constants observed in frog
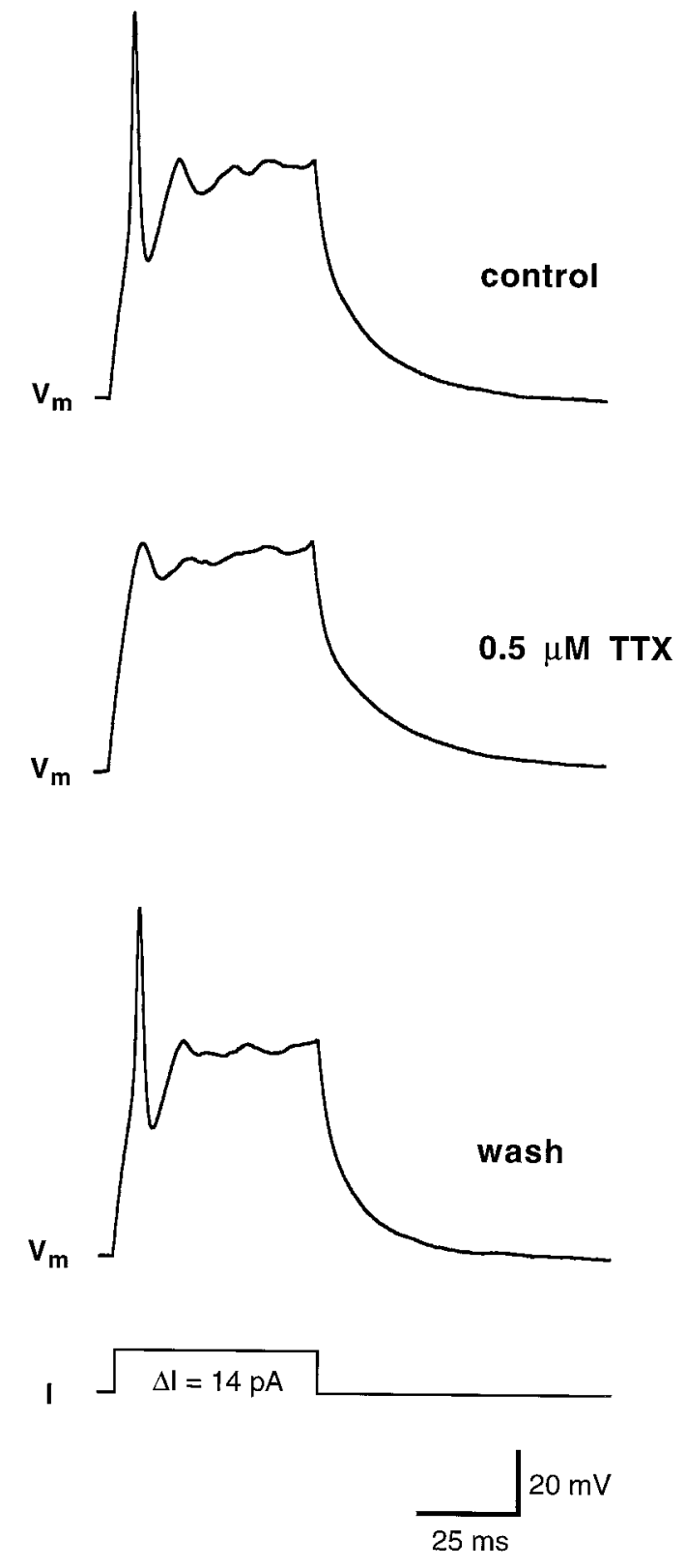

Figure 9. Contribution of sodium currents to action potential in wing cells. The cell was held at approximately $-80 \mathrm{mV}$, and a $14 \mathrm{pA}$ pulse of current was injected. In control conditions (bath solution: APS) an action potential was fired (top). In the presence of $0.5 \mu \mathrm{M}$ TTX, the same stimulation protocol failed to elicit a spike-like action potential (middle). In voltage-clamp configuration, the inward $\mathrm{Na}^{+}$currents were completely abolished (data not shown). After the drug was washed out, wing cell membrane recovered the capability of firing action potential (bottom). Pipette solution was standard $105 \mathrm{mM} \mathrm{KCl} . V_{\mathrm{m}}$, Membrane potential.

chemosensory cells [15.6 msec (Avenet and Lindemann, 1987) and 9.7 msec (Miyamoto et al., 1991)].

\section{Voltage-gated $\mathrm{K}^{+}$currents}

The outward currents that remained after the voltage-gated $\mathrm{Na}^{+}$ current was blocked with TTX (Fig. $3 A$ ) were carried by potassium ions, as indicated by their sensitivity to TEA (Fig. $5 A$ ) and by their reduction when $\mathrm{CsCl}$ was used instead of $\mathrm{KCl}$ in the pipette solution (Fig. $3 B$ ). $\mathrm{K}^{+}$current inactivated over time and was voltage-dependent, as indicated by the $I-V$ curve in Figure 
$5 B$. This curve shows that the current begins activating at potentials above $-40 \mathrm{mV}$, whereas at potential values ranging from -40 to $+10 \mathrm{mV}$, current increases almost linearly and reaches a plateau at a membrane depolarization $>10-20 \mathrm{mV}$. Finally, its magnitude decreases by further depolarization (Fig. $5 B$ ). This behavior suggests possible involvement of a $\mathrm{Ca}^{2+}$-activated $\mathrm{K}^{+}$ current. Indeed, the $I-V$ curve seemed to show initial features of the "N" shape characteristic of these currents (Hille, 1992). We assessed whether this was the case by adding to the bath $10 \mathrm{~mm}$ $\mathrm{Co}^{2+}$, a known $\mathrm{Ca}^{+}$channel blocker (Hagiwara and Byerly, 1981). Under this condition there was a reduction of $\mathrm{K}^{+}$currents at a given membrane potential, but the overall shape of the $I-V$ curve did not change (Fig. 6). This suggests that in the presence of $\mathrm{Co}^{2+}$, the threshold for outward current activation was shifted in a positive direction, presumably because of the effect of the high concentration of divalent cations on the external surface charge of the membrane (Hille, 1992). We found no compelling evidence for a Ca-mediated $\mathrm{K}^{+}$conductance. Furthermore, as will be shown below, there is no evidence for voltage-gated $\mathrm{Ca}^{2+}$ currents.

In regular APS, the $\mathrm{K}^{+}$current reached a peak between 20 and $60 \mathrm{mV}$ and averaged $645.0 \pm 269.9 \mathrm{pA}$ (mean $\pm \mathrm{SD}$; range 315 to $1334.4 \mathrm{pA} ; n=24)$. During a prolonged depolarization (200 msec), the $\mathrm{K}^{+}$current displayed a strong inactivation. Figure $7 \mathrm{~A}$ shows an example of the $\mathrm{K}^{+}$current elicited in a wing cell by stepping the membrane to $+15 \mathrm{mV}$ from a holding potential of $-85 \mathrm{mV}$ : at this voltage, the time course of inactivation could be fitted with a single exponential function with a time constant of $24.7 \pm 2.5 \mathrm{msec}($ mean $\pm \mathrm{SD} ; n=3)$, which is consistent with the presence of a single channel type. Finally, inactivation of these currents was voltage dependent, as typifies A current in molluscan neurons (Connor and Stevens, 1971). Figure $7 B$ shows the effect of holding potential $\left(V_{\mathrm{h}}\right)$ on the inactivation of $\mathrm{K}^{+}$currents as recorded from an isolated wing cell: currents were totally abolished by depolarizing the cell membrane at approximately $-30 \mathrm{mV}$ or more. Inactivating $\mathrm{K}^{+}$currents have been described in rod taste cells of the frog (Avenet and Lindemann, 1987; Miyamoto et al., 1991) as well as in taste cells of other vertebrates (Béhé et al., 1990; Sugimoto and Teeter, 1990; Bigiani and Roper, 1993; Chen et al., 1996). These cells also showed sustained $\mathrm{K}^{+}$ currents, indicating that more than one type of potassium channel contributed to the outward currents. On the contrary, our data suggest that only one type of voltage-gated $\mathrm{K}^{+}$channel occurs in the membrane of the wing cells.

\section{Lack of voltage-gated $\mathrm{Ca}^{2+}$ currents}

To test for the presence of voltage-gated $\mathrm{Ca}^{2+}$ currents in wholecell configuration, we designed specific pipette and bath solutions aimed at completely eliminating voltage-gated $\mathrm{Na}^{+}$and $\mathrm{K}^{+}$currents and potentiating the currents through the $\mathrm{Ca}^{2+}$ channels in the recorded cells (see Materials and Methods). However, we were not able to detect voltage-gated $\mathrm{Ca}^{2+}$ currents in any wing cells tested ( $n=9$ cells; data not shown). We obtained the same negative results when we added $2 \mathrm{~mm}$ ATP to the pipette solution ( $n=6$ cells; data not shown) to reduce rundown of $\mathrm{Ca}^{2+}$ currents (Bean, 1992). We also use the perforated-patch recording (Horn and Marty, 1988; Korn et al., 1991) to test for $\mathrm{Ca}^{2+}$ currents in wing cells. However, even in this experimental condition, no $\mathrm{Ca}^{2+}$ current could be detected ( $n=5$ cells; data not shown). Therefore, we concluded that active voltage-gated $\mathrm{Ca}^{2+}$ channels were not present in the wing cells investigated.
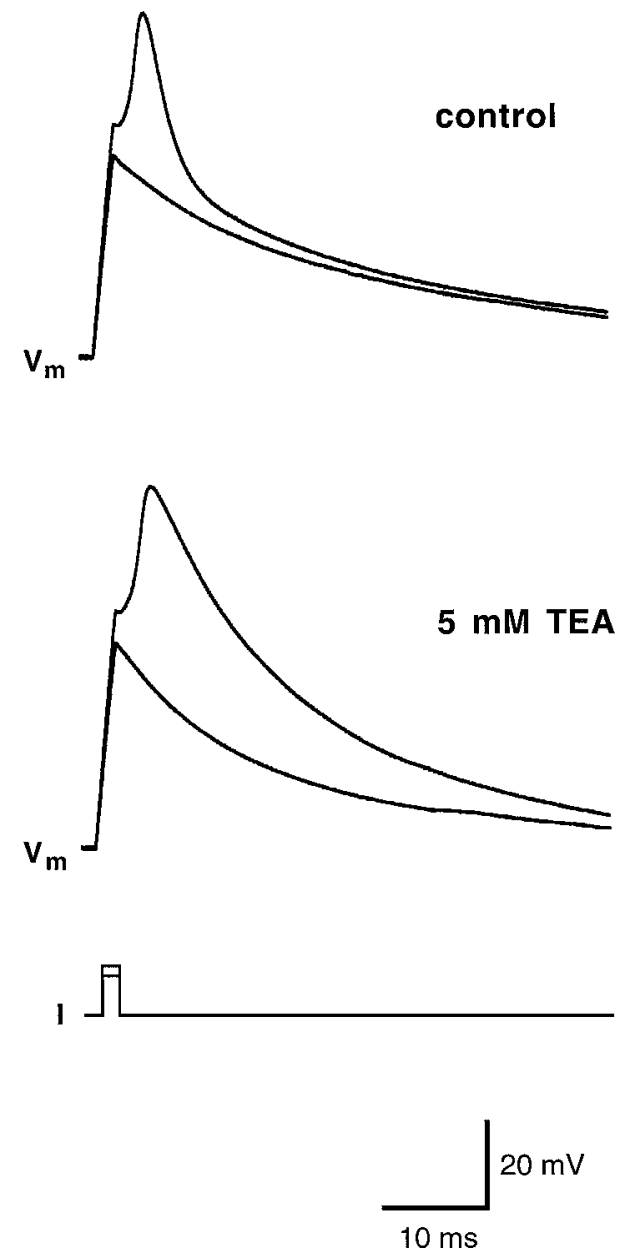

Figure 10. Contribution of potassium currents to the repolarization phase of the action potential in wing cells. Cell membrane was held at approximately $-80 \mathrm{mV}$, and two current pulses were injected. The first pulse $(70 \mathrm{pA})$ was subthreshold, whereas the second one $(80 \mathrm{pA})$ elicited an action potential (top, control). When $5 \mathrm{~mm}$ TEA was applied, the action potential broadened considerably (bottom). In voltage-clamp configuration, the inactivating $\mathrm{K}^{+}$current was completely abolished (data not shown). Pipette solution was standard $105 \mathrm{~mm} \mathrm{KCl} . V_{\mathrm{m}}$, Membrane potential.

\section{Action potentials in response to current injections}

The presence of voltage-gated $\mathrm{Na}^{+}$currents suggested that wing cells can generate action potentials. Under current-clamp conditions, when the cell was held hyperpolarized at approximately $-80 \mathrm{mV}$ and stimulated with depolarizing current pulses, it was possible to generate action potentials (Fig. 8), as shown previously in chemosensory cells of the frog taste disk by Avenet and Lindemann (1987) and Miyamoto et al. (1991). The threshold for action potentials was approximately $-40 \mathrm{mV}$, and their duration was approximately $5 \mathrm{msec}$. Wing cell action potentials were similar to the "fast" action potentials described in rat taste cells (Béhé et al., 1990; Chen et al., 1996). In wing cells, however, action potentials could not be generated repetitively, even with prolonged depolarizing current pulses (data not shown). Application of TTX completely blocked the action potential (Fig. 9), whereas TEA increased its duration (Fig. 10). This latter observation indicated that, as shown in rat taste cells (Chen et al., 1996), the inactivating $\mathrm{K}^{+}$currents played a role in the repolarizing phase of the action potential in wing cells. 


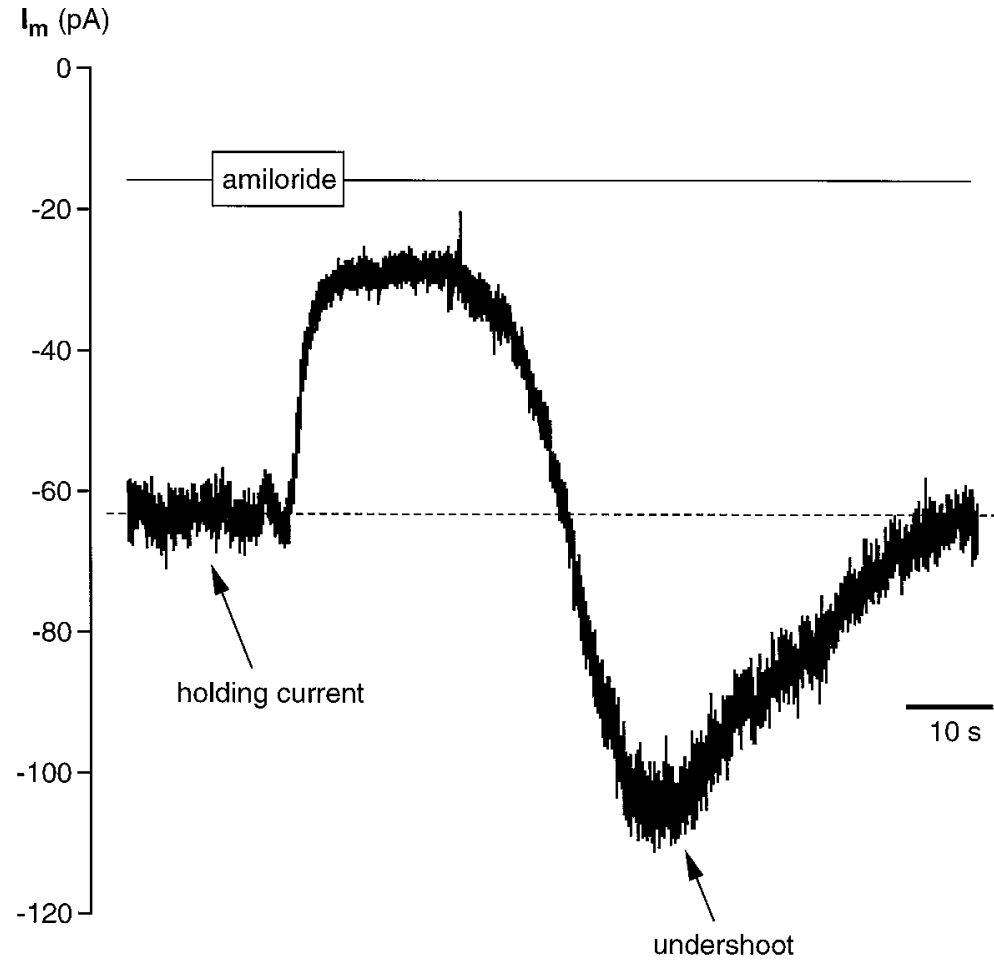

$V_{h}=-75 \mathrm{mV}$
Figure 11. Response of whole-cell current to amiloride in an isolated wing cell. Cell membrane was held at $-75 \mathrm{mV}$. Bath application of $40 \mu \mathrm{M}$ amiloride in regular APS caused a rapid decrease in the stationary inward current (holding current) and in current noise. Note the undershooting transient (undershoot) on washout of amiloride. Pipette solution was standard $105 \mathrm{~mm} \mathrm{CsCl} . I_{\mathrm{m}}$, Membrane current.

\section{Amiloride-sensitive $\mathrm{Na}^{+}$currents}

Sodium ions occurring in food are thought to be detected by taste chemosensory cells through specific $\mathrm{Na}^{+}$channels sensitive to amiloride (for review, see Lindemann, 1996; Stewart et al., 1997). These channels differ fundamentally from the voltage-sensitive, TTX-sensitive channels (Garty and Benos, 1988). The presence of amiloride-sensitive $\mathrm{Na}^{+}$channels in the cell membrane of taste cells can be shown by studying the effect of amiloride on the whole-cell current recorded at a given holding potential (Avenet and Lindemann, 1988; Gilbertson et al., 1993; Doolin and Gilbertson, 1996). In isolated wing cells, we looked for evidence of amiloride-sensitive currents by holding them at negative potentials and by bath-applying amiloride in standard APS solution. We used an amiloride concentration ranging from 30 to $40 \mu \mathrm{M}$ because these values proved to block effectively amiloridesensitive $\mathrm{Na}^{+}$channels in taste receptor cells of the frog and other vertebrates (Avenet and Lindemann, 1988; Gilbertson et al., 1993; Doolin and Gilbertson, 1996). In 14 of 19 cells (74\%), amiloride caused a reduction in the stationary inward currents recorded when cell membrane was held at negative potentials. Figure 11 shows an example of the effect of amiloride on the stationary inward current recorded from a wing cell held at -75 $\mathrm{mV}$. It is interesting to note that during the washout, the membrane current transiently increased (Fig. 11, undershoot) before relaxing to the baseline level. This increase could be attributable to the known self-inhibition by $\mathrm{Na}^{+}$described for the amiloridesensitive $\mathrm{Na}^{+}$channels (Garty and Palmer, 1997). Moreover, the time course of the amiloride effect on wing cells was remarkably similar to the one observed by Avenet and Lindemann (1988) in rod taste cells of the frog. Concomitant to the decrease in the stationary inward current we measured an increase in the cell input resistance (Fig. 12) that was consistent with channels being closed by amiloride. The increase in input resistance elicited by $30 \mu \mathrm{M}$ amiloride ranged from 58 to $290 \%$ of the control values $\left(n=4\right.$ cells). Replacing extracellular $\mathrm{Na}^{+}$with a large impermeant cation, NMDG, caused a reduction of the stationary inward current similar to the effect of amiloride (Fig. 13). With NMDG, however, no undershoot was observed during the washout (Fig. 13). Collectively these observations suggested that wing cells possessed amiloride-sensitive $\mathrm{Na}^{+}$channels in their membrane.

\section{Variability of voltage-gated currents in wing and rod taste cells}

The voltage-gated $\mathrm{Na}^{+}$and $\mathrm{K}^{+}$currents showed similar properties in all the wing cells tested. For example, the $\mathrm{K}^{+}$currents recorded from different wing cells always presented a marked inactivation, and all wing cells possessed voltage-gated $\mathrm{Na}^{+}$currents. These observations suggested that wing cells were a homogeneous population of taste cells as far as their voltage-gated ion channels are concerned. In contrast, voltage-gated currents in rod cells were considerably varied, in agreement with findings of previous studies (Avenet and Lindemann, 1987; Miyamoto et al., 1988, 1991). Figures 14 and 15 show examples of recordings from different rod cells isolated along with the wing cells. Some rod cells (Fig. 14) did not show any detectable voltage-gated $\mathrm{Na}^{+}$ currents and possessed $\mathrm{K}^{+}$currents without inactivation during the voltage protocol used (compare Fig. $14 B$ with Fig. $7 A$ ). Other rod cells, however, presented voltage-gated $\mathrm{Na}^{+}$currents in association with noninactivating $\mathrm{K}^{+}$currents (Fig. 15A), and some others showed membrane currents quite indistinguishable from those observed in wing cells (Fig. 15B). Like wing cells, all the rod cells tested $(n=5)$ did not present active voltage-gated $\mathrm{Ca}^{2+}$ channels in our experimental conditions (data not shown), in 


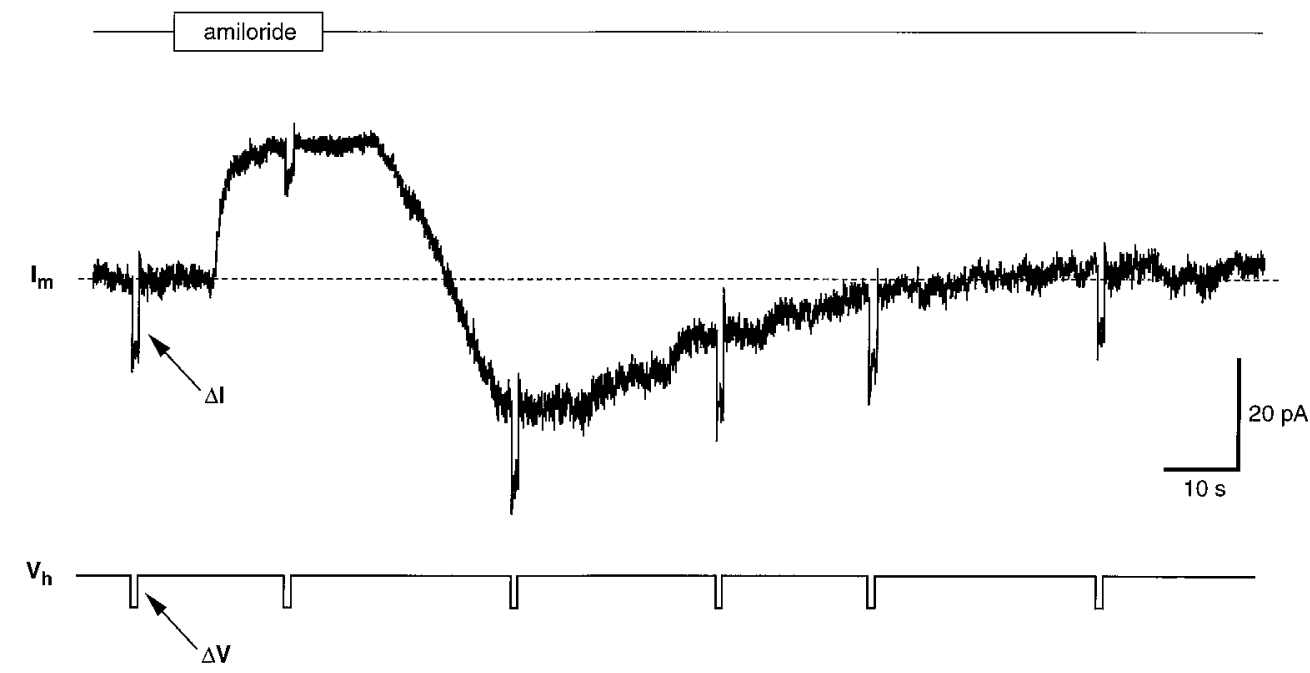

Figure 12. Change in the input resistance of a wing cell during response to amiloride $(30 \mu \mathrm{M})$. Input resistance was monitored by application of -20 $\mathrm{mV}$ steps from a holding potential $\left(V_{\mathrm{h}}\right)$ of $-75 \mathrm{mV}$. Input resistance increased from $1.6 \mathrm{G} \Omega$ before amiloride application to $3.9 \mathrm{G} \Omega$ during the amiloride response, suggesting that membrane conductance was reduced. Note that during washout, cell input resistance recovered to the control value. $I_{\mathrm{m}}$, Membrane current.

agreement with previously published data (Avenet and Lindemann, 1987; Miyamoto et al., 1991).

\section{DISCUSSION}

One of the challenging issues in taste research is the evaluation of the functional properties of the different cell types occurring in vertebrate taste organs. The goal of our study was to contribute to the understanding of functional diversification between taste cells. In detail, we have examined the following question: what are the membrane properties of taste cells lacking synaptic contacts with afferent axons (i.e., the so-called supporting cells)? As a model we chose a cell from the frog taste disk, the wing cell. Studies with extensive use of serial sections have revealed that wing cells do not synapse onto afferent nerve terminals (Osculati and Sbarbati, 1995). Wing cells are considered secretory elements involved in the production of the material covering the free surface of the taste organ (for review, see Osculati and Sbarbati, 1995). Their distinctive sheet-like process fills the space between other cells in the taste disk, and their cytoskeleton apparently lends mechanical support to the other cellular elements (Richter et al., 1988). Unlike wing cells, chemosensory elements in frog taste disk are spindle-shaped, with a rod-like apical process. They are subdivided into two groups, Type II and Type III cells (for review, see Osculati and Sbarbati, 1995). In this study, we found that wing cells possessed some membrane properties remarkably similar to those observed in the chemosensory elements. Voltagegated $\mathrm{Na}^{+}$and $\mathrm{K}^{+}$channels typically found in chemosensitive rod cells are also expressed by wing cells. We could not reveal any significant variability in the properties of these channels among wing cells, which in this respect made up a homogeneous cell population. By contrast, we observed a certain variability in the membrane properties of rod cells, confirming previous data (Avenet and Lindemann, 1987; Miyamoto et al., 1988, 1991). This result is probably related to the heterogeneous composition of chemosensory cells. Voltage-gated $\mathrm{Ca}^{2+}$ channels are thought to subserve chemical transmission in taste buds (Lindemann, 1996) and are found in many vertebrate taste cells (Kinnamon and Roper, 1988; Béhé et al., 1990; Sugimoto and Teeter, 1990; Bigiani and Roper, 1993; Chen et al., 1996). Consistently with the
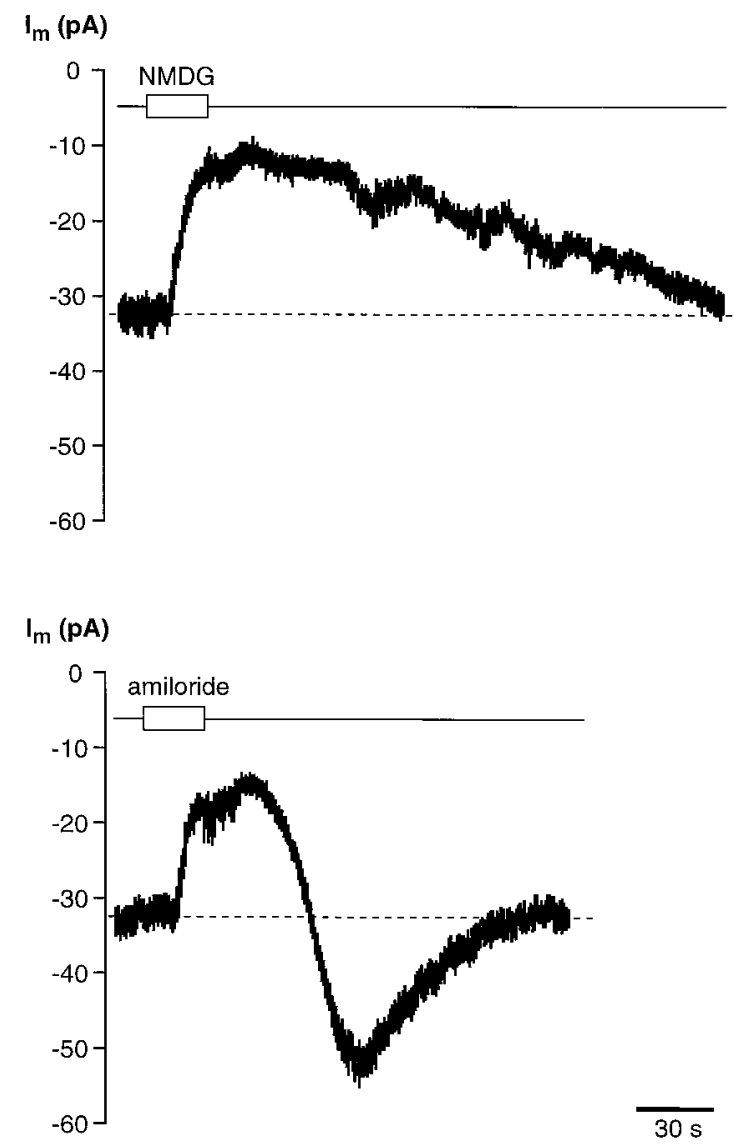

Figure 13. Effect of $\mathrm{Na}^{+}$-free saline and amiloride on the stationary inward current $\left(I_{\mathrm{m}}\right)$ recorded from an isolated wing cell held at $-60 \mathrm{mV}$. Replacing extracellular $\mathrm{Na}^{+}$with NMDG, a large impermeant cation, induced a decrease in the stationary inward current (top trace) similar to that elicited by bath-applying $30 \mu \mathrm{M}$ amiloride to the same cell (bottom trace). However, time courses of the current recovery during washout were markedly different. 
A
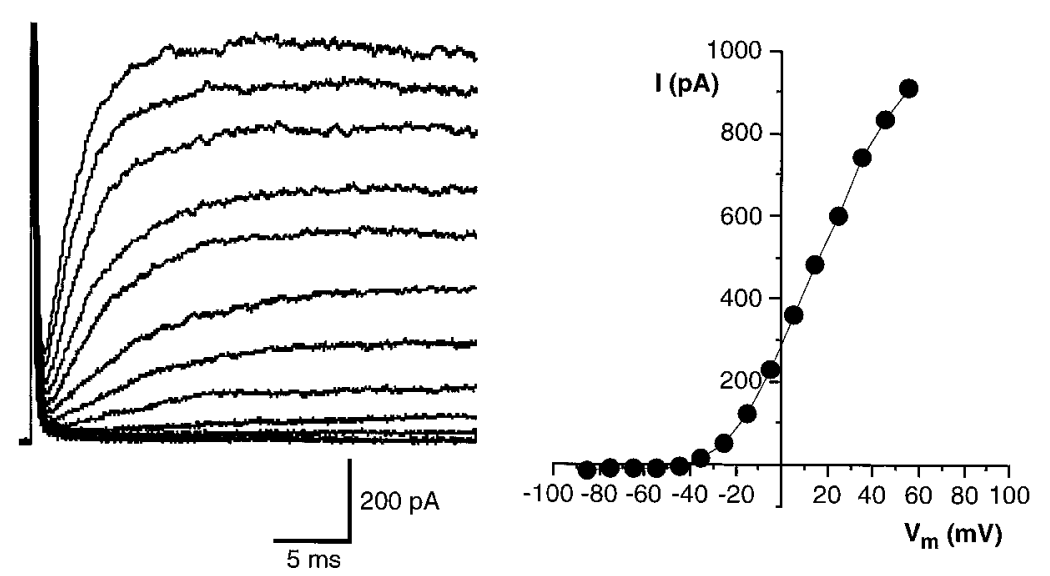

B
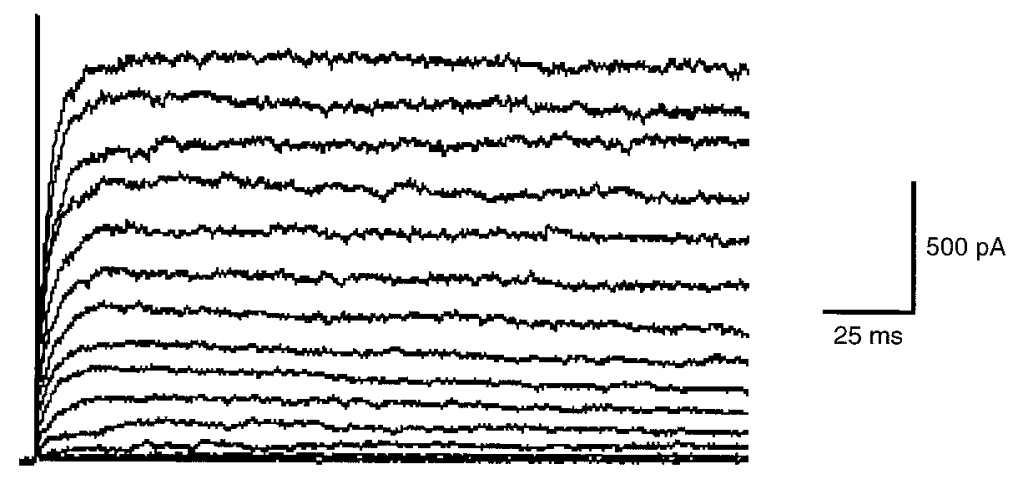

lack of chemical synapses, we could not detect any voltage-gated $\mathrm{Ca}^{2+}$ currents in wing cells. However, we have to point out that rod cells in frog taste disks also do not posses voltage-gated $\mathrm{Ca}^{2+}$ channels (Avenet and Lindemann, 1987; Miyamoto et al., 1991; present study), despite the observation that they make synaptic contacts with afferent nerve terminals (Osculati and Sbarbati, 1995). In conclusion, putative supporting elements share with the chemosensory cells the absence of these channels, at least in frog. Currently there is no obvious explanation for this peculiarity of frog taste cells. It is to be noted that in a recent study Kolesnikov and Margolskee (1995) described a cyclic nucleotide-suppressible conductance permeable to $\mathrm{Ca}^{2+}$ in frog taste cells (presumably rod ones), which could represent the major pathway of $\mathrm{Ca}^{2+}$ influx in these cells. It would be interesting to test whether a similar conductance is present in wing cells.

By using the freeze-fracture technique, Sbarbati et al. (1993) showed that the apical membrane of wing cells displays intramembrane particles similar to those found in Type III cells: accordingly, our functional findings showed that the membrane of wing cells indeed displays ion channels similar to those found in the chemosensory elements of frog taste disks. Yet wing cells have not been shown to make chemical synaptic contacts with afferent axons. On this basis, it is tempting to speculate that the morpho-f unctional properties of wing cells would resemble those of glial cells in the nervous system. It is well established that oligodendrocytes and astrocytes in the CNS and Schwann cells in
Figure 14. Whole-cell recordings from isolated rod cells lacking voltage-gated $\mathrm{Na}^{+}$currents. $A$, Outward currents (left) elicited in regular APS by a series of depolarizing pulses between -75 and $+55 \mathrm{mV}$, in $10 \mathrm{mV}$ increments, from a holding potential of $-85 \mathrm{mV}$. The corresponding $I-V$ plot (right) indicated that the outward current in this cell activated at approximately $-40 \mathrm{mV}$. These recordings were obtained from the cell shown in Figure $1 B . B$, Outward currents recorded in another rod cell. Voltage protocol was the same as for the cell in $A$, but the pulse duration was 200 msec. It can be noted that in this cell the outward current did not inactivate significantly during the stimulation period (compare with the time course of inactivation shown in Fig. 7A). Capacitative and leakage currents were not subtracted in these recordings. Pipette solution was standard $105 \mathrm{~mm} \mathrm{KCl}$. the PNS are endowed with a vast array of voltage-gated ion channels, neurotransmitter-gated channels, and transport mechanisms similar to those found in the adjacent neurons (for review, see Barres et al., 1990; Ritchie, 1992). The physiological functions of these membrane proteins remain to be fully elucidated, although some hypotheses have been postulated. For example, it has been proposed that glial cells act as local sources of axolemmal $\mathrm{Na}^{+}$channels, thereby reducing the biosynthetic load of neurons (Gray and Ritchie, 1985; Sontheimer et al., 1996). Voltage-gated $\mathrm{K}^{+}$channels have been suggested to play a role in the homeostasis of $\mathrm{K}^{+}$released in the extracellular space by active neurons (Ritchie, 1992). In the retina, Müller cells are astrocyte-like cells expressing voltage-gated ion channels, neurotransmitter receptors, and various uptake carrier systems (for review, see Newman and Reichenbach, 1996). These properties enable the Müller cells to control the activity of retinal neurons by regulating the extracellular concentration of neuroactive substances such as $\mathrm{K}^{+}$, GABA, and glutamate. In addition, it has been proposed that voltage-gated $\mathrm{Na}^{+}$channels in these cells could be activated by the functioning of adjacent neurons; this way, glial cells could sense the activity of neighboring neurons (Chao et al., 1994). In taste organs, cells are closely apposed, and the extracellular space around them is very narrow. The sheetlike processes of wing cells fill the space between adjacent taste cells, and their large surface area makes these cells suitable for controlling the extracellular fluid inside the taste organs and 
A

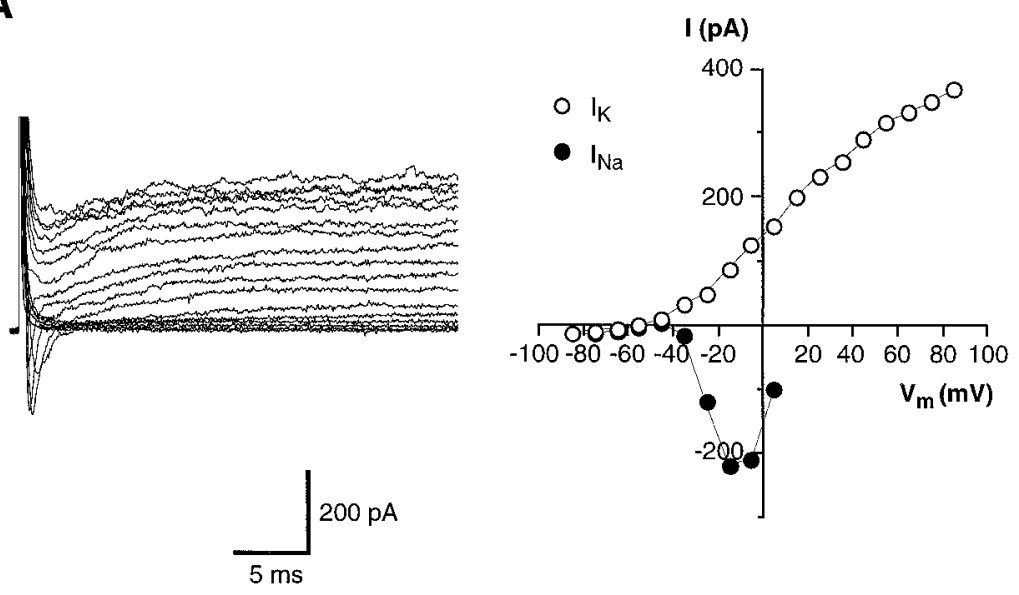

B

Figure 15. Whole-cell recording from other rod cells showing various membrane ionic currents. $A$, Transient inward $\mathrm{Na}^{+}$current and sustained outward $\mathrm{K}^{+}$currents recorded from an isolated rod cell (left). The $I-V$ plots for these currents are shown on the right. Voltage-clamp protocol: holding potential, $-85 \mathrm{mV}$; depolarizing pulses in $10 \mathrm{mV}$ increments from -75 to $+85 \mathrm{mV}$. Capacitative and leakage currents were not subtracted in these recordings. $B$, Voltagegated currents recorded from another isolated rod cell (left) with their corresponding $I-V$ plots $(r i g h t)$. Note that the currents were similar to those recorded in the wing cells (for example, compare with Fig. 2). Voltage-clamp protocol was the same as in $A$. Capacitative and leakage currents were subtracted in these recordings. Pipette solution was standard $105 \mathrm{~mm} \mathrm{KCl}$.

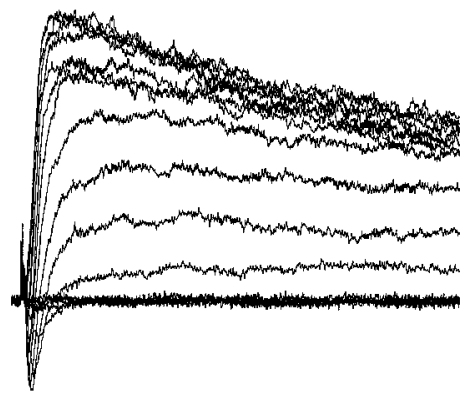

perhaps for monitoring the activity of adjacent chemosensory cells. Wing processes also ensheathe the apical processes of chemosensory elements (Richter et al., 1988). Therefore, in view of the narrow intercellular spaces, a glia-like control of extracellular ion and transmitter concentrations seems to be a plausible hypothesis. In this respect, it would be interesting to test whether wing cells are electrically coupled as the glial cells are in the nervous system (Dermietzel and Spray, 1993).

In addition to voltage-gated channels, wing cells also possessed amiloride-sensitive $\mathrm{Na}^{+}$channels, which are thought to mediate, at least in some vertebrates, the chemotransduction of sodium taste (for review, see Lindemann, 1996; Stewart et al., 1997). These channels have been studied in rod taste cells of the frog by Avenet and Lindemann (1988). Although wing cells express functional amiloride-sensitive $\mathrm{Na}^{+}$channels, it is possible that their properties differ from those of the same channels occurring in rod cells. Further investigation is required to assess, for example, the inhibition constant of amiloride block, which in rod cells is very low $(0.3 \mu \mathrm{M})$ (Avenet and Lindemann, 1988). Our data did not allow us to establish the location (apical, basolateral, or both) of the amiloride-blockable $\mathrm{Na}^{+}$channels in wing cells. Iontophoretic application of amiloride could help in mapping the amiloride sensitivity of wing cell membrane. However, the presence of these channels raises the possibility that wing cells may be involved in the chemotransduction of $\mathrm{Na}^{+}$salts in taste organs. In this regard, it is interesting to point out that amiloride-sensitive $\mathrm{Na}^{+}$channels have also been identified in nontaste epithelial cells surrounding taste buds ( $\mathrm{Li}$ et al., 1994). It has been proposed that amiloride-sensitive $\mathrm{Na}^{+}$channels in these cells could play a role in the transcellular pathway for current flow within and outside the taste organ during activation of the chemosensory elements by sodium ions (Li et al., 1994; Lindemann, 1996). It is then possible that during taste stimulation with $\mathrm{Na}^{+}$, loop currents flow between receptor cells and neighboring "associated" cells such as wing cells. In short, these cells could participate in the early signal chain of gustatory reception.

Taste cells similar to the wing type in frog occur also in the taste buds of other vertebrates. Type I cells in mammals present sheet-like lateral projections filling the space between adjacent Type II and Type III cells, thereby providing an organizing element for the structure of the bud (rabbit: Royer and Kinnamon, 1994; rat: Pumplin et al., 1997). Dark cells (Type I) in Necturus have a lamellar apical process too (Delay and Roper, 1988; Kinnamon et al., 1988). Finally, scanning electron micrographic studies have revealed the presence of taste cells with lamellar process in mouse (Spielman et al., 1992). In summary, given the similarity of frog wing cells to Type I cells in other vertebrates, it would be tempting to speculate that these taste cells could play a glial-like role in the functioning of taste sensory organs. It is important also to point out that there is a certain variability from one species to the other as to the structural properties of Type I cells. For example, these cells house synaptic contacts with afferent nerves in Necturus (Delay and Roper, 1988) and in mouse (Kinnamon et al., 1985; but see Seta and Toyoshima, 1995), whereas in frog (Osculati and Sbarbati, 1995) and rat (Takeda and Hoshino, 1975) they do not. It is possible that 
variability in structure and function of taste cell types may reflect varying nutritional requirements among species. Along this line, a given cell type may have both chemosensory and supportive functions in some species, whereas in others it could be more specialized. Comparative studies (Kim and Roper, 1995) may help in obtaining a comprehensive picture of the morphofunctional correlation for vertebrate taste cells.

\section{REFERENCES}

Akabas MH, Dodd J, Al-Awqati Q (1990) Identification of electrophysiologically distinct subpopulations of rat taste cells. J Membr Biol 114:71-78.

Avenet P, Lindemann B (1987) Patch-clamp study of isolated taste receptor cells of the frog. J Membr Biol 97:223-240.

Avenet P, Lindemann B (1988) Amiloride-blockable sodium currents in isolated taste receptor cells. J Membr Biol 105:245-255.

Barres BA, Chun LLY, Corey DP (1990) Ion channels in vertebrate glia. Annu Rev Neurosci 13:441-474.

Barry PH, Lynch JW (1991) Liquid junction potentials and small cell effects in patch clamp analysis. J Membr Biol 121:101-117.

Bean BP (1992) Whole-cell recording of calcium channel currents. Methods Enzymol 207:181-193.

Béhé B, DeSimone JA, Avenet P, Lindemann B (1990) Membrane currents in taste cells of the rat fungiform papilla: evidence for two types of $\mathrm{Ca}$ currents and inhibition of K currents by saccharin. J Gen Physiol 96:1061-1084.

Belles B, Malécot CO, Hescheler J, Trautwein W (1988) "Run-down" of the $\mathrm{Ca}$ current during long whole-cell recordings in guinea pig heart cells: role of phosphorylation and intracellular calcium. Pflügers Arch 411:353-360.

Bigiani A, Roper SD (1993) Identification of electrophysiologically distinct cell subpopulations in Necturus taste buds. J Gen Physiol 102:143-170.

Bigiani A, Kim DJ, Roper SD (1996) Membrane properties and cell ultrastructure of taste receptor cells in Necturus lingual slices. J Neurophysiol 75:1944-1956.

Chao TI, Skachkov SN, Eberhardt W, Reichenbach A (1994) $\mathrm{Na}^{+}$channels of Muller (glial) cells isolated from retinae of various mammalian species including man. Glia 10:173-185.

Chen Y, Sun XD, Herness S (1996) Characteristics of action potentials and their underlying outward currents in rat taste receptor cells. J Neurophysiol 75:820-831.

Connor JA, Stevens CF (1971) Voltage clamp studies of a transient outward membrane current in gastropod neural somata. J Physiol (Lond) 213:21-30.

Delay RJ, Roper SD (1988) Ultrastructure of taste cells and synapses in the mudpuppy Necturus maculosus. J Comp Neurol 277:268-280.

Dermietzel R, Spray DC (1993) Gap junctions in the brain: where, what type, how many and why? Trends Neurosci 16:186-192.

Doolin RE, Gilbertson TA (1996) Distribution and characterization of functional amiloride-sensitive sodium channels in rat tongue. J Gen Physiol 107:545-554.

Fujiyama R, Miyamoto T, Sato T (1993) Non-selective cation channel in bullfrog taste cell membrane. NeuroReport 5:11-13.

Fujiyama R, Miyamoto T, Sato T (1994) Differential distribution of two $\mathrm{Ca}^{2+}$-dependent and -independent $\mathrm{K}^{+}$channels throughout receptive and basolateral membranes of bullfrog taste cells. Pflügers Arch 429:285-290.

Garty H, Benos DJ (1988) Characteristics and regulatory mechanisms of the amiloride-blockable $\mathrm{Na}^{+}$channel. Physiol Rev 68:309-373.

Garty H, Palmer LG (1997) Epithelial sodium channels: function, structure and regulation. Physiol Rev 77:359-395.

Gilbertson TA, Kinnamon SC, Roper SD (1993) Proton currents through amiloride sensitive $\mathrm{Na}^{+}$channels in isolated hamster taste cells: enhancement by vasopressin and cAMP. Neuron 10:931-942.

Gray PT, Ritchie JM (1985) Ion channels in Schwann and glial cells. Trends Neurosci 8:411-415.

Hagiwara S, Byerly L (1981) Calcium channel. Annu Rev Neurosci 4:69-125.
Hamill OP, Marty A, Neher E, Sakmann B, Sigworth FJ (1981) Improved patch-clamp techniques for high-resolution current recording from cells and cell-free membrane patches. Pflügers Arch 391:85-100.

Herness MS, Sun XD (1995) Voltage-gated sodium currents recorded from dissociated rat taste cells. J Membr Biol 146:73-84.

Hille B (1992) Ionic channels of excitable membranes. Sunderland, MA: Sinauer.

Horn R, Marty A (1988) Muscarinic activation of ionic currents measured by a new whole-cell recording method. J Gen Physiol 92:145-159.

Jaeger CB, Hillman DE (1976) Morphology of gustatory organs. In: Frog neurobiology (Llinàs R, Precht W, eds), pp 588-604. Berlin: Springer.

Kim DJ, Roper SD (1995) Localization of serotonin in taste buds: a comparative study in four vertebrates. J Comp Neurol 353:364-370.

Kinnamon SC, Roper SD (1988) Membrane properties of isolated mudpuppy taste cells. J Gen Physiol 91:351-371.

Kinnamon JC, Taylor BJ, Delay RJ, Roper SD (1985) Ultrastructure of mouse vallate taste buds. I. Taste cells and their associated synapses. J Comp Neurol 235:48-60.

Kinnamon SC, Cummings TA, Roper SD (1988) Isolation of single taste cells from lingual epithelium. Chem Senses 13:355-366.

Kolesnikov SS, Margolskee RF (1995) A cyclic-nucleotide-suppressible conductance activated by transducin in taste cells. Nature 376:85-88.

Korn SJ, Horn R (1989) Influence of sodium-calcium exchange on calcium current rundown and the duration of calcium-dependent chloride currents in pituitary cells, studied with whole cell and perforated patch recording. J Gen Physiol 94:789-812.

Korn SJ, Marty A, Connor JA, Horn R (1991) Perforated patch recording. Methods Neurosci 4:364-373.

Li X-J, Blackshaw S, Snyder SH (1994) Expression and localization of amiloride-sensitive sodium channel indicate a role for non-taste cells in taste perception. Proc Natl Acad Sci USA 91:1814-1818.

Lindemann B (1996) Taste reception. Physiol Rev 76:719-766.

McPheeters M, Barber AJ, Kinnamon SC, Kinnamon JC (1994) Electrophysiological and morphological properties of light and dark cells isolated from mudpuppy taste buds. J Comp Neurol 346:601-612.

Miyamoto T, Okada Y, Sato T (1988) Membrane properties of isolated frog taste cells: three types of responsivity to electrical stimulation. Brain Res 449:369-372.

Miyamoto T, Okada Y, Sato T (1991) Voltage-gated membrane current of isolated bullfrog taste cells. Zool Sci 8:835-845.

Miyamoto T, Miyazaki T, Okada Y, Sato T (1996) Whole-cell recording from non-dissociated taste cells in mouse taste bud. J Neurosci Methods 64:245-252.

Neher E (1992) Correction for liquid junction potentials in patch clamp experiments. Methods Enzymol 207:123-131.

Newman E, Reichenbach A (1996) The Müller cell: a functional element of the retina. Trends Neurosci 19:307-312.

Okada Y, Miyamoto T, Sato T (1994) Activation of a cation conductance by acetic acid in taste cells isolated from the bullfrog. J Exp Biol 187:19-32.

Osculati F, Sbarbati A (1995) The frog taste disc: a prototype of the vertebrate gustatory organ. Prog Neurobiol 46:351-399.

Pumplin DW, Yu C, Smith DV (1997) Light and dark cells of rat vallate taste buds are morphologically distinct cell types. J Comp Neurol 378:389-410.

Richter HP, Avenet P, Mestres P, Lindemann B (1988) Gustatory receptors and neighboring cells in the surface layer of an amphibian taste disc: in situ relationships and response to cell isolation. Cell Tissue Res 254:83-96.

Ritchie JM (1992) Voltage-gated ion channels in Schwann cells and glia. Trends Neurosci 15:345-351.

Roper SD (1989) The cell biology of vertebrate taste receptors. Annu Rev Neurosci 12:329-353.

Royer SM, Kinnamon JC (1994) Application of serial sectioning and three-dimensional reconstruction to the study of taste bud ultrastructure and organization. Microsc Res Tech 29:381-407.

Sbarbati A, Zancanaro C, Ferrara P, Franceschini F, Accordini C, Osculati F (1993) Freeze-fracture characterization of cell types at the surface of the taste organ of the frog, Rana esculenta. J Neurocytol $22: 118-127$. 
Seta Y, Toyoshima K (1995) Three-dimensional structure of the gustatory cell in the mouse fungiform taste buds: a computer-assisted reconstruction from serial ultrathin sections. Anat Embryol 191:83-88.

Sontheimer H, Black JA, Waxman SG (1996) Voltage-gated $\mathrm{Na}^{+}$channels in glia: properties and possible functions. Trends Neurosci 19:325-331.

Spielman AI, Mody I, Brand JG, Whitney G, MacDonald JF, Salter MW (1989) A method for isolating and patch-clamping single mammalian taste receptor cells. Brain Res 503:326-329.

Spielman AI, Ricketts-Foot DA, Brand JG (1992) High resolution scanning electron micrographic study of dissociated mouse taste cells. Chem Senses 17:451-460.
Stewart RE, DeSimone JA, Hill DL (1997) New perspectives in gustatory physiology: transduction, development, and plasticity. Am J Physiol 272:C1-C26.

Sugimoto K, Teeter JH (1990) Voltage-dependent ionic currents in taste receptor cells of the larval tiger salamander. J Gen Physiol 96:809-834.

Takeda M, Hoshino T (1975) Fine structure of taste buds in the rat. Arch Histol Jpn 37:395-413.

Zancanaro C, Sbarbati A, Franceschini F, Balercia G, Osculati F (1990) The chemoreceptor surface of the taste disc in the frog, Rana esculenta. An ultrastructural study with lanthanum nitrate. Histochem J 22: 480-486. 